\title{
MINERAL RESOURCE POTENTIAL OF THE SWEETWATER ROADLESS AREA, MONO COUNTY, CALIFORNIA, AND LYON AND DOUGLAS COUNTIES, NEVADA
}

\author{
SUMMARY REPORT
}

By

G. F. Brem, M. A. Chaffee, and Donald Plouff

U.S. Geological Survey

R. H. Lambeth, H. W. Campbell, D. F. Scott, and J. M. Spear

U.S. Bureau of Mines

\section{STUDIES RELATED TO WILERRESS}

Under the provisions of the Wilderness Act (Public Law 88-577, September 3, 1964) and related acts, the U.S. Geological Survey and U.S. Bureau of Mines have been conducting mineral surveys of wilderness and primitive areas. Areas officially designated as "wilderness," "wild," or "canoe" when the act was passed were incorporated into the National Wilderness Preservation System, and some of them are presently being studied. The act provided that areas under consideration for wilderness designation should be studied for suitability for incorporation into the Wilderness System. The mineral surveys constitute one aspect of the suitability studies. The act directs that the results of such surveys are to be made available to the public and be submitted to the President and the Congress. This report discusses the results of a mineral resource potential survey of the Sweetwater Roadless Area (4-657), Toiyabe National Forest, Mono County, California, and Lyon and Douglas Counties, Nevada. The Sweetwater Roadless Area was classified as a further planning area during the Second Roadless Area Review and Evaluation (RARE II) by the U.S. Forest Service, January 1979.

\section{SUMMARY}

A 9-mi ${ }^{2}$ intensely altered area underlain by middle Miocene rhyolite of the Sweetwater volcanic center along the east side of the study area and two smaller areas within and east of the roadless area have a high to moderate resource potential for epithermal vein or disseminated silver and gold deposits. Since 1882, mines chiefly east of the roadless area have had an estimated production of $\$ 3,000,000$, primarily in precious metals. Within the roadless area, extensive mineralization is indicated by assays of numerous vein, dump, and rock samples. The podiform nature of vein deposits, inaccessibility of underground workings, sporadic occurrence of disseminated mineralization, and extensive surficial deposits generally precluded estimation of mineral resources.

An area roughly coincident with the zone of Tertiary alteration and precious-metal enrichment has a moderate resource potential for a disseminated-molybdenum deposit. Anomalously high molybdenum abundances occur in shear zones, intensely altered rock, and veins in Tertiary rhyolite of the Sweetwater volcanic center within the same area as precious-metal mineralization. Lithologic characteristics, alteration, geochemical anomalies, and geophysical anomalies in the Tertiary rhyolitic rocks suggest a deep-seated Tertiary disseminated-molybdenum system. Molybdenum, in the form of molybdenite, also occurs in quartz veinlets in granite and was deposited during a Late Cretaceous mineralization event in plutonic rocks just east of the roadless area. The mineral resource potential for molybdenum in the granitic rocks is low because of unfavorable host-rock and mineraldeposit characteristics.

Three areas within and adjacent to the roadless area have a low or moderate resource potential for iron, copper, tungsten, gold, or uranium in thermally metamorphosed and metasomatized volcanic and sedimentary rocks. Moderate-sized metamorphic rock bodies are indicated by geophysical data; however, favorable carbonate facies within the bodies are of limited areal extent and exhibit only weak geochemical anomalies. Manganese occurs in three areas, but has a low resource potential.

The study area has nonmetallic mineral resource potential for silica and geothermal energy. One area has a low resource potential for silica, a pegmatitic quartz body vein. One area has a low resource potential for geothermal energy based on reservoir temperature and volume characteristics.

\section{INTRODUCTION}

The U.S. Geological Survey and the U.S. Bureau of Mines conducted a survey to evaluate the mineral resource potential of the Sweetwater Roadless Area during 1979-82. The roadless area, in east-central California and Nevada (fig. 1), encompasses some 72,240 acres of the Sweetwater Mountains in the Toiyabe National Forest near Bridgeport, Calif. The area is highlighted by a series of barren peaks along the crest of the range that are underlain by leached or brightly colored Mesozoic basement and Tertiary volcanic rocks. Elevations range from $11,673 \mathrm{ft}$ on Mount Patterson to $6,160 \mathrm{ft}$ near Devils Gate on the East Walker River. The climate of the area is semiarid. Vegetation ranges from a cold-steppe plant community of sage, forbs, and sparse conifers in protected sites at high elevations, to pinyonjuniper forests on side slopes, to a community of sage, grasses, and forbs on the lowest valley floors. Access to the area is from U.S. Highway 395 on the south and west, Risue Road on the north, and Nevada Highway 338 and California Highway 182 on the east. Several graded and unimproved dirt roads provide access to the west and east flanks of the range.

\section{GEOLOGY, GEOCHEMISTRY, AND GEOPHYSICS PERTAINING TO MINERAL RESOURCE ASSESSMENT}

\section{GEOLOGY}

The Sweetwater Mountains, just east of the Sierra Nevada, contain a Mesozoic basement complex of dominantly silicic plutonic rocks with septa and roof pendants of metamorphic rocks that is nonconformably overlain by middle and upper Tertiary volcanic rocks and upper Tertiary(?) and Quaternary surficial deposits (Brem, 1983).

Metamorphic rocks crop out over less than 5 percent of the roadless area. The metamorphic protolith assemblage 
consisted of marine calcareous and tuffaceous clastic sedimentary rocks or intermediate to felsic volcanic rocks of Late Triassic(?) to Late Cretaceous age (Halsey, 1953; Schweickert, 1972, 1976) that have been thermally metamorphosed by plutonic rocks. The metamorphic rocks, particularly calcareous facies, are favorable hosts for iron, copper, and tungsten deposits primarily in skarn bodies near contacts with plutonic rocks and for gold and uranium deposits in silicified shear zones.

Plutonic rocks, predominantly Late Cretaceous in age, are exposed over about 20 percent of the roadless area. Granite is the most abundant rock type, however rocks range from gabbro to granite in composition. The plutonic rocks become more felsic and exhibit fewer thermal metamorphic effects with decreasing age. Plutonic rock compositions range from gabbro in the oldest pluton through maficmineral-rich granite to mafic-mineral-poor granite and granitic aplite in the youngest plutons. The oldest and intermediate age plutons, such as the Swauger Creek, Desert Creek, and East Fork, are bleached by metamorphism or have different mafic minerals near contacts with younger plutons. Multiple intrusive episodes and possible surface venting during pluton emplacement are suggested in the East Fork pluton where small irregularly shaped intrusions with finer grain size and more silicic composition intrude more mafic-mineral-rich granite. The East Fork and Green Creek plutons have been locally altered and mineralized with pyrite and molybdenite in four areas during Late Cretaceous mineralization events possibly related to the complex intrusive history of the East Fork pluton. A pegmatitic quartz body occurs within the Swauger Creek pluton, but is probably related to the granite of Devils Gate-Mack Canyon.

The metamorphic and plutonic rock assemblages in the study area are comparable to assemblages found in much of the Sierra Nevada and western Great Basin and may be related to a Mesozoic Andean-type arc along the west edge of North America (Dickinson, 1976). Mineral deposits within these rocks, as well as those within the roadless area, commonly include disseminated and quartz-vein molybdenum or contact-metasomatic tungsten, iron, copper, molybdenum, or gold types.

Upper Oligocene to upper Miocene volcanic rocks nonconformably overlie plutonic and metamorphic rocks and crop out over nearly 50 percent of the roadless area. The volcanic rocks and related mineralization events here and in adjacent parts of the Sierra Nevada and western Great Basin provinces are generally similar because the entire region is part of the same magmatic arc related to the subduction of the Farallon Plate beneath the west coast of North America (Dickinson, 1979; Dickinson and Snyder, 1979).

The oldest volcanic rocks in the Sweetwater Roadless Area are the upper Oligocene to lower Miocene Valley Springs Formation which consists of a few outcrops of silicic welded tuff that is not related to alteration or mineralization. The unconformably overlying middle Miocene Relief Peak Formation crops out discontinuously throughout the roadless area and consists of andesite lahar with less abundant autobrecciated flow, flow, or domal rocks. The andesite is weakly to strongly propylitized, except where more intense, local alteration and mineralization has occurred during events associated with rhyolitic volcanism.

Rhyolitic rocks are generally younger than the andesite and crop out throughout the roadless area. The rhyolitic rocks consist of a series of dikes and effusive rocks concentrated primarily in the central part of the range that have been informally named the Sweetwater volcanic center (Brem, 1982). Tuff and pyroclastic rhyolitic tuff breccia dominate the inner part of the center, whereas lava flows, dikes, and domal extrusions dominate the periphery. Much, if not all, of the rhyolitic rocks were extruded or intruded along a north-trending dike system. The dikes trend northerly irrespective of basement lithology and have steep to moderate dips that are inclined toward the north-trending central axis of the volcanic center. The rhyolite generally intrudes andesite of the Relief Peak Formation, although andesite is locally intercalated with rhyolite. In the central part of the Sweetwater volcanic center, the rhyolite, as well as the underlying rock, is intensely altered, mineralized, and contains silver, gold, and geochemically related metals in north-trending quartz veins, silicified shear zones, and possibly in disseminated deposits (Sutley and others, 1983). Anomalous concentrations of molybdenum and tin in these same rocks may indicate a deep-seated disseminatedmolybdenum system.

Southwest of roadless area, latitic rocks of the upper Miocene Stanislaus Group from the Little Walker volcanic center (Brem, 1977; 1983) unconformably overlie andesite and rhyolite along much of the southeastern and southwestern part of the Sweetwater Mountains. This latitic sequence, consisting of latite lava flows and welded to nonwelded quartz latite ash-flow tuffs, postdates alteration and mineralization of the rhyolite and is not recognizably altered. Fales Hot Springs, located on the ring-fracture system of the Little Walker caldera, has a low resource potential for geothermal energy.

The late Tertiary and Quaternary history of the area reflects one of volcanic quiescence, but moderate to intense tectonic activity. Initial late Tertiary(?) uplift of the Sierra Nevada is suggested by the deposition from northeastwardflowing streams of coarse alluvial gravels of uncertain age along the northern and southern Sweetwater Mountains. Quaternary uplift of the Sweetwater Mountains and westward rotation of the entire range are indicated by a reversal of these early drainage patterns and by fanglomerates and normal faults along the east side of the range. The range today stands chiefly as a single fault block with few recognized large-displacement internal faults except for older normal faults along the southeast side of the range. Many small-displacement faults undoubtedly exist, particularly within the volcanic units, but remain unrecognized because of the prolonged and complex volcanic activity, hydrothermal alteration, and surficial or masswasting processes.

\section{GEOCHEMISTRY}

The geochemical investigation of the Sweetwater Roadless Area was based on the analysis of 127 rock, 59 stream-sediment, and 59 nonmagnetic heavy-mineralconcentrate samples (Sutley and others, 1983). Some rock samples were collected in order to provide information on the normal or background chemical abundances, whereas other rock samples from obviously mineralized and (or) hydrothermally altered outcrops and from selected mine dumps were collected to provide information about chemical abundances in potentially anomalous areas. Stream-sediment samples provide information about the chemical elements present in rock materials eroded from the drainage basin upstream from each sample site, and the composition of these samples identifies those basins that contain unusually high concentrations of elements that may be related to mineral deposits. Nonmagnetic heavy-mineral-concentrate samples were derived from the same active alluvium as stream-sediment samples. These concentrate samples provide information about selected elements in a limited number of minerals that may be ore related.

Some stream-sediment and heavy-mineral-concentrate samples include contaminating materials from mine dumps. It is assumed, in this reconnaissance study, that the contaminating material was from rock mined within that basin, and thus, the chemical effects of mining activity have a negligible effect on the mineral resource assessment.

All three types of samples were analyzed for 31 elements ( $\mathrm{Ag}, \mathrm{As}, \mathrm{Au}, \mathrm{B}, \mathrm{Ba}, \mathrm{Be}, \mathrm{Bi}, \mathrm{Ca}, \mathrm{Cd}, \mathrm{Co}, \mathrm{Cr}, \mathrm{Cu}, \mathrm{Fe}$, La, Mg, Mn, Mo, Nb, Ni, Pb, Sb, Sc, Sn, Sr, Th, Ti, V, W, Y, $\mathrm{Zn}$, and $\mathrm{Zr}$ ) using a six-step semiquantitative emission spectrographic method. In addition, rock and streamsediment samples were analyzed for bismuth, cadmium, antimony, and zine by atomic-absorption spectrometry, and for arsenic by colorimetry; selected samples were analyzed for gold by atomic-absorption spectrometry.

Geochemical data were evaluated by the SCORESUM technique (Chaffee, 1983). In this technique, the range in concentration values for each element selected in streamsediment and concentrate samples was divided into four categories at approximately the 90th, 95th, and 98th 
percentiles utilizing statistics available in the U.S. Geological Survey RASS-STATPAC system (VanTrump and Miesch, 1977). The values were given a "score" of $0,1,2$, or 3 representing background, weakly anomalous, moderately anomalous, and strongly anomalous concentration levels. Scores were summed for all elements selected in each sample type to give a total geochemical anomaly score for the sample site. Thus, the assessment of weak, moderate, or strong geochemical anomalies for a site is based on the number of elements that are anomalous as well as the concentration levels of those elements. Areas and intensities of geochemical anomalies were then determined by plotting the total geochemical anomaly score (SCORESUMS) for each site on a topographic base map subdivided into drainage basins.

Certain elements, tabulated below for each sample type, were selected as having anomalous concentrations that might be related to mineralization or alteration. For concentrate samples, elements selected as being related to mineralization were further subdivided into base- and precious-metal or molybdenum-tungsten suites.

\begin{tabular}{lll} 
Sample type & $\frac{\text { Element suite }}{\mathrm{Ag}, \mathrm{As}, \mathrm{Au}, \mathrm{Ba},}$ & Indication \\
\hline Rock & $\mathrm{Be}, \mathrm{Bi}, \mathrm{Cd}, \mathrm{Cu}$ \\
& $\begin{array}{l}\mathrm{Mo}, \mathrm{Pb}, \mathrm{Sb}, \mathrm{Sn}, \\
\mathrm{W}, \mathrm{Zn}\end{array}$
\end{tabular}

Stream sediment

$\mathrm{Ag}, \mathrm{As}, \mathrm{Au}, \mathrm{Be}$

Mineralization

$\mathrm{Bi}, \mathrm{Cd}, \mathrm{Cu}, \mathrm{Mn}$, $\mathrm{Mo}, \mathrm{Pb}, \mathrm{Sb}, \mathrm{Sn}$, $\mathrm{Zn}$

Concentrate $\mathrm{Ag}, \mathrm{As}, \mathrm{Au}, \mathrm{Be}$, $\mathrm{Bi}, \mathrm{Cd}, \mathrm{Cu}, \mathrm{Mo}$ $\mathrm{Pb}, \mathrm{Sb}, \mathrm{Sn}, \mathrm{W}$, $\mathrm{Zn}$

$\mathrm{Ag}, \mathrm{As}, \mathrm{Au}$,
$\mathrm{Cd}, \mathrm{Cu}, \mathrm{Pb}$,
$\mathrm{Sb}, \mathrm{Zn}$

Base- and preciousmetal suite

$$
\begin{aligned}
& \mathrm{Be}, \mathrm{Bi}, \mathrm{Mo}, \\
& \mathrm{Sn}, \mathrm{W}
\end{aligned}
$$

Molybdenumtungsten suite

Hydrothermal alteration

\section{GEOPHYSICS}

Geophysical studies used for mineral resource assessment of the roadless area consisted of gravity and aeromagnetic surveys that were compiled in isostatic residual gravity and aeromagnetic maps (Donald Plouff, unpub. data, 1983). The isostatic residual gravity map was derived from a compilation of published gravity data (Plouff, 1982a). Gravity determinations at 175 stations were contoured at a 2mGal interval. The only prominent gravity low within the general study area is a 4- by 14-mi gravity low attributed to more than $4,000 \mathrm{ft}$ of tuffaceous rocks in the Little Walker caldera southwest of the roadless area (Plouff, 1982b).

Several small gravity anomalies are present. A gravity low between Wheeler Peak and Mount Patterson may reflect the lower density of a thick succession of intensely altered dominantly pyroclastic rocks that correspond to the central zone of alteration and mineralization in the Sweetwater volcanic center. Small gravity highs near Sheeles Camp and near the Bridgeport Ranger Station probably reflect a higher density of underlying metamorphic rocks compared to the density of surrounding plutonic and Tertiary volcanic rocks. A prominent gravity high near South Sister may indicate an underlying body of metamorphic rocks, although other rock types could be present.

An aeromagnetic map was prepared from two surveys that were drape flown at $1,000 \mathrm{ft}$ above the ground along flight lines spaced at $0.5-$ and $1.0-\mathrm{mi}$ intervals (U.S. Geological Survey, 1979; 1982). The flight path tended to be closer to the ground over peaks than over valleys. Because surface rocks generally have normal magnetizations, magnetic highs consequently tend to occur over hilltops and ridges and magnetic lows tend to occur over valleys.

Two magnetic lows, approximately $2 \mathrm{mi}$ in diameter, extend northeast from Wheeler Peak and south of Star City and these lows generally correspond to areas of intensely altered volcanic rocks. Other irregularly shaped magnetic highs probably indicate relatively thick accumulations of unaltered volcanic rocks at the north end of the roadless area, north of the Bridgeport Ranger Station, and north of Fales Hot Springs.

Several magnetic anomalies are located over plutonic rocks. A complex magnetic high extends about $7 \mathrm{mi}$ northward along the crest of the Sweetwater Mountains from Mount Patterson. The northern part of the magnetic high near Middle Sister may reflect the higher magnetization of an extensive body of granite underlying Middle Sister. Farther south along this magnetic high, similar plutonic or possibly metamorphic rocks are presumed to underlie the magnetic high, although only small exposures of the granite of East Fork and metamorphic rocks crop out within an extensive area of Tertiary volcanic rocks. The granite of East Fork may not be the source of the magnetic high as this pluton has only a low to moderate magnetization in other parts of the roadless area. Other magnetic anomalies overlying plutonic rocks are generally related to variations in plutonic rock composition and magnetization.

Metamorphic rocks generally have a moderate to high magnetization as reflected by magnetic highs located outside the roadless area east of Sweetwater Creek, west of the Bridgeport Ranger Station, and near Sheeles Camp. A circular-shaped magnetic high near the north end of Bridgeport Reservoir may represent an underlying body of metamorphic rocks, as such rocks crop out within an apparent northeast extension of the circular-shaped anomaly. A magnetic low in upper Sweetwater Creek is associated with magnetite-bearing metamorphic rocks which suggests that some metamorphic rocks are reversely magnetized.

\section{MINING DISTRICTS AND MINERALIZATION}

\section{Present Studies}

U.S. Bureau of Mines personnel researched pertinent Federal and county mining-claim records and files to determine claim locations and mining activity. Sixty-two mines and prospects were mapped and sampled by U.S. Bureau of Mines personnel during this study (fig. 2; table 1). A comprehensive report and all sample analyses are on file at the U.S. Bureau of Mines, Western Field Operations Center, Spokane, Washington.

Eight hundred forty-one rock samples were taken during the U.S. Bureau of Mines investigation. Three varieties of rock samples were taken: chip, grab, and select. Most were chip samples collected normal to a mineralized horizon or vein. Grab samples were collected from mine and prospect dumps to obtain an approximate grade. Select samples were often taken of the apparent highest grade material in a mineralized zone particularly in probable lowgrade occurrences. Samples were taken for petrographic analysis at each prospect.

The samples were crushed, pulverized, and split. Each was routinely examined for abnormally high radioactivity to test for uranium and examined for fluorescence to determine the presence of tungsten minerals. Most samples were analyzed for gold and silver by fire-assay methods. When required, quantitative values of other elements were measured by atomic-absorption analysis, colorimetry, fluorimetry, cold-vapor atomic-absorption spectrometry, or inductively coupled argon spectrometry. At least one sample from each mineralized feature was checked by semiquantitative emission spectroscopy for anomalous content of 42 
elements $(\mathrm{Ag}, \mathrm{Al}, \mathrm{As}, \mathrm{Au}, \mathrm{B}, \mathrm{Ba}, \mathrm{Be}, \mathrm{Bi}, \mathrm{Ca}, \mathrm{Cd}, \mathrm{Co}, \mathrm{Cr}, \mathrm{Cu}$, $\mathrm{Fe}, \mathrm{Ga}, \mathrm{Hf}$, In, La, Li, Mg, Mn, Mo, $\mathrm{Na}, \mathrm{Nb}, \mathrm{Ni}, \mathrm{P}, \mathrm{Pb}, \mathrm{Pt}, \mathrm{Rh}$, $\mathrm{Sb}, \mathrm{Sc}, \mathrm{Si}, \mathrm{Sn}, \mathrm{Sr}, \mathrm{Ta}, \mathrm{Te}$, Th, Ti, V, Y, $\mathrm{Zn}$, and $\mathrm{Zr}$ ); anomalous contents were checked by more quantitative methods.

\section{Historical mining activity}

The Patterson mining district includes all of the California part of the Sweetwater Roadless Area. Prospecting began in the Sweetwater Mountains in the 1850's during the same time mineral discoveries were being made in the nearby Bodie and Masonic districts. The Patterson mining district was organized in 1880 , and by 1882 , many of the mineralized areas were being developed and the Kentuck mine (No. 38, fig. 2; table 1) was producing silver. By 1888 , mines in the district had produced approximately $\$ 500,000$ $(450,000 \mathrm{oz})$ of silver with most of the production from the Kentuck mine (Whiting, 1888).

Mining activity waned after the closing of the Kentuck mine in 1885 and only sporadic activity occurred in the district until 1925. From 1904 until 1925, the Monte Cristo mine (No. 49) produced $650 \mathrm{oz}$ of silver and $90 \mathrm{oz}$ of gold, reworking of the Kentuck mill tailings produced 24,000 oz of silver and $156 \mathrm{oz}$ of gold, the Silverado mine (No. 36) produced an unknown amount of silver, and other mines and prospects in the area may have produced minor amounts of precious metals, but have no recorded production. The Silverado mine was worked from 1925-29 and 1933-39. Estimated total production of the mine is $3,000,000 \mathrm{oz}$ of silver, $3,000 \mathrm{oz}$ of gold, and $35,000 \mathrm{lb}$ of copper, much of which was produced between 1933-39 (Lambeth and others, 1983).

Besides the Silverado mine, only minor mining activity is recorded in the Patterson district from 1932 until the present. Small amounts of molybdenite were produced from prospects in Green Creek during the period 1932 to 1935. Prospecting for precious metals; contact deposits of iron, copper, tungsten, gold and uranium; and manganese occurred at various times. Recently, major mining companies have been exploring for disseminated-molybdenum and epithermal precious-metal deposits.

Total value of mineral production for the district is estimated to be about $\$ 3,000,000$ on the basis of recorded mineral production and accounts of workers in the district (Hanks, 1884; Whiting, 1888; Eakle and McLaughlin, 1917; Tucker, 1927; Bradley, 1927; Symons, 1928, 1929, 1935, 1936, $1937,1938,1939$, Lambeth and others, 1983).

\section{Mining claims}

Federal and county mining records indicate approximately 2,500 claims have been located in or adjacent to the study area. The majority of these are within 2 or $3 \mathrm{mi}$ of old mines, and almost all are lode claims. Approximately 300 claims in the study area and 200 claims adjacent to the area were maintained in 1982. The Star and Great Western claims, which contain 39.36 acres, are patented and lie within the study area (No. 19). Twenty-four lode claims incorporating the Silverado-Kentuck mine areas have been patented, as have one lode claim at the Longstreet mine (No. 53), and one lode claim and a millsite at the Monte Cristo mine. During 1981, several holes were drilled near the study area to establish a regional geothermal gradient, but no geothermal lease applications have been filed (Wayne Frye, oral commun., 1983).

\section{Geology of deposits}

Mineralization is of several general types: epithermal precious metals (silver and gold); hydrothermal molybdenum associated with volcanic and granitic rocks; contactmetasomatic iron, copper, gold, tungsten, and uranium; manganese of several origins; and quartz pegmatite. A low potential for geothermal energy also exists nears Fales Hot Springs.

Precious-metal deposits of the epithermal vein (bonanza) and disseminated types are associated with rhyolitic volcanic rocks and occur within and to the east of the roadless area (areas $\mathrm{Al}, \mathrm{A} 2$, and $\mathrm{A} 3$, fig. 3). Vein deposits occur in sheared, intensely silicified, argillized, or sericitized rhyolitic rocks erupted from the Sweetwater volcanic center (Brem, 1982; Hunter, 1976). Typically, lenticular quartz veins from a few inches to several feet thick contain podiform bodies of argentite and (or) acanthite with minor hessite, galena, argentiferous galena, and native silver in a gangue of quartz, adularia, chalcedony, pyrite, minor fluorite, and rhyolite fragments. The veins are generally north-trending and dip moderately to steeply. These veins were assigned to three northerly trending belts by Whiting (1888)-the Cameron belt which corresponds to area A2, and the Clinton and Comstock belts which correspond to area Al. Deposits within each belt are comparable, although gold is slightly more abundant in the Cameron belt.

Disseminated precious-metal deposits are possible, particularly around the major vein systems with known mineral production such as the Kentuck-Silverado and California Comstock-Star and Great Western systems or in porous tuff and brecciated rock such as around the Monte Cristo mine and Wheeler Peak.

Gold and silver have been found in several areas not underlain by rhyolitic rocks. Traces of silver were found in a leached and slightly silicifed shear zone in andesite at the mouth of Water Canyon (No. 56; area A4). Gold and silver occur in silicified contact-metamorphic rocks north of Sweetwater Canyon (No. 12; area A5). The Longstreet mine (no. 53; area A6) was reportedly developed for gold, although no metal values were found in samples taken from the mine.

Molybdenum mineralization is associated with the precious-metal mineralization in the rhyolitic rocks in areas M1, M2, and M3. Although hypogene molybdenum minerals were generally not observed, geochemical analyses of veins, altered rock, and weakly altered shear zones indicate widespread occurrence of molybdenum, from background amounts of less than 10 parts per million to 0.11 percent (Lambeth and others, 1983; Sutley and others, 1983). A disseminated molybdenum system buried within or beneath Tertiary volcanic rocks may be indicated by the complex rhyolitic volcanic history, within an atectonic setting, magnetic and gravity lows suggestive of altered and low density rock, presence of fluorite and huebnerite, and strong geochemical anomalies of molybdenum, base metals, and other ore-related elements, and an epithermal silver system and its associated alteration.

Molybdenum mineralization also occurred during Late Cretaceous mineralization events associated with the East Fork and Green Creek plutons in the four small areas M4, M5, M6, and M7 just outside of the roadless area. In each area, molybdenite occurs in quartz veinlets or in quartz-sericite altered zones no larger than a few thousand square feet . Radiometric dating of sericite believed to be associated with molybdenum mineralization in Silverado Canyon yielded a Late Cretaceous age (C. P. Miller, oral commun., 1980). The mineralization age is considered to be similar for the other occurrences.

Contact-metasomatic deposits of iron, copper, tungsten, gold, and uranium are possible near contact zones between granitic plutonic rocks and septa or roof pendants of metamorphic rocks with carbonate lenses.

Iron and copper deposits occur near Sweetwater Canyon (No. 14, IC2) and Lobdell Lake (No. 6 and 10; ICl). Typically, the deposits consist of replacement bodies of disseminated to massive magnetite, traces of copper-bearing sulfides, and massive serpentine in carbonate-bearing lenses. The deposits are most commonly found within, but are not restricted to, contact zones with granitic or dioritic rocks. Individual deposits are generally only a few feet wide and less than $100 \mathrm{ft}$ long, although one deposit in Sweetwater Canyon (No. 14) can be traced along strike for about $1,000 \mathrm{ft}$. Metamorphic rocks of similar character occur in the Swauger Creek area (No. 52; area IC3); however, iron and copper mineralization has not been recognized in this area.

The metamorphic rocks also locally contain precious metals, tungsten, and uranium. Precious metals, as discussed previously, occur in silicified shear zones in Sweetwater Canyon (area A5) and trace amounts of precious metals are associated with calc-silicate minerals near Swauger Creek (No. 52; area IC3). Tungsten occurs near Swauger Creek (No. 
52; area W3) in a calc-silicate skarn mineral assemblage, and a low potential also exists for tungsten in the two other metamorphic bodies (areas W1 and W2). Uranium occurs only west of Lobdell Lake (Nos. 8 and 9; area Ul) where silicifed shear zones within metavolcanic rocks contain small amounts of uranium.

Manganese occurs in brecciated volcanic rocks or manganiferous quartz veins in granite in three areas (MNl, MN2, and MN3) with outcrop areas of less than a few thousand square feet. These are possibly of hot-spring or hydrothermal-vein origin (Lambeth and others, 1983).

Quartz occurs in two nearly circular pegmatite bodies with the mafic complex of Swauger Creek in one area (No. 57; area S1) east of Swauger Creek. The quartz bodies have a thin feldspar shell suggesting that the bodies are pegmatites derived from the nearby granite of Devils Gate-Mack Canyon. Other pegmatitic bodies are rare within the study area; however, pegmatitic quartz bodies are known from similar granite outerops approximately $8 \mathrm{mi}$ south of the study area.

Geothermal resources are most likely in the Fales Hot Springs area just south of the study area (No. 59, area $\mathrm{Gl}$ ). The hot springs are located on the ring fracture of the Little Walker volcanic center; however, a late Miocene age for the youngest volcanic rocks in the center would suggest that the current hot-spring activity may be related to more recent tectonic activity rather than hot volcanic rocks or magma.

\section{ASSESSMENT OF MINERAL RESOURCE POTENTIAL}

The mineral resource potential of the Sweetwater Roadless Area has been evaluated on the basis of the following criteria: 1) host-rock composition, structure, and alteration; 2) known mineral occurrences; 3) geochemical anomalies in samples of rock, stream sediment, and nonmagnetic heavy-mineral concentrates; 4) aeromagnetic and gravity anomalies; and 5) mining activity. Map areas assigned a high to moderate resource potential for various types of mineral deposits have favorable characteristics in at least three of these criteria; areas assigned a low to moderate resource potential have fewer favorable characteristics.

\section{Precious metals}

The mineral resource potential for epithermal vein and disseminated silver and gold deposits associated with rhyolitic volcanic rocks is high to moderate based on strongly favorable characteristics in all five criteria. Favorable hostrock characteristics include numerous intrusive bodies, abundant shearing and brecciation, extensive deposits of porous tuff, and widespread intensive alteration. Strong geochemical anomalies for a wide spectrum of ore-related elements in all types of samples are highly favorable as are known mineral occurrences. Additionally, areas Al and A2 have associated magnetic and gravity lows suggesting the presence of a thick body of low-density altered rock.

The mineral resource potential for precious metals in rock types other than rhyolite are low primarily because shear and alteration zones are not large or well developed, geochemical anomalies and mineral occurrences are weak, and geophysical characteristics are not supportive of large features.

The following tabulation lists areas with a preciousmetal resource potential, evaluation of the areas as to potential, and a summary of data supporting the assignment of potential.

\section{Area \\ (fig. 3) \\ Resource potential}

A1
High

\section{Assessment criteria}

a) Rhyolitic host rocks have maximum thicknesses and greatest petrologic diversity of any locality in roadless area. b) Intensely silicified and mineralized north-trending shear zones and veins and locally
Moderate

\section{Assessment criteris}

silicified porous or brecciated rhyolitic host rocks within a larger zoned epithermal alteration system.

c) Silver- and gold-bearing area with recorded mineral production of about $3,400,000 \mathrm{oz}$ of silver, $3,000 \mathrm{oz}$ of gold, and $35,000 \mathrm{lb}$ of copper primarily east of the roadless area.

d) Strong geochemical anomalies of numerous elements in streamsediment samples, and of elements of the base- and precious-metal suite and hydrothermal alteration suite in heavy-mineral-concentrate

samples.

e) Selected vein, dump, and altered-rock samples have low to high precious-metal abundances. f) 120,000 tons of resources averaging $\mathrm{ll} \mathrm{oz}$ of silver per ton at the Silverado mine; 4,500 ton occurrence averaging $7.8 \mathrm{oz}$ of silver and $0.06 \mathrm{oz}$ of gold per ton at the California Comstock.

g) Gravity and magnetic lows suggest a thick accumulation of low-density altered rock.

a) Host rock consists of rhyolitic intrusive and extrusive rocks of the Sweetwater volcanic center. b) Pervasively silicified and epithermally altered porous rhyolitic host rock and veins, silic sinter, abundant adularia.

c) Moderate geochemical anomalies of selected elements in stream-sediment samples and weak anomalies of base- and precious-metal suite elements in heavy-mineral-concentrate samples.

d) Moderate anomaly of orerelated elements, and low to moderate gold and silver assay values in vein and altered rocks around the Monte Cristo mine.

e) Gravity and magnetic lows suggest a thick accumulation of low-density rock.

a) Host rock consists of rhyolitic intrusive and extrusive rocks of the Sweetwater volcanic center.

b) Intensely silicified 30-ft-wide shear zone and argillized host rock.

c) Moderate geochemical anomaly of selected elements in a streamsediment sample, and moderate to strong anomalies of elements of the base- and precious-metal suite and hydrothermal alteration suite in heavy-mineral-concentrate samples.

d) Weak geochemical anomaly of ore-mineral related elements, and very low assay values for silver in altered rock and vein samples.

a) Relief Peak Formation andesite host rock. 
b) Silicified and leached zone 22

$\mathrm{ft}$ wide by $300 \mathrm{ft}$ long.

c) Weak geochemical anomaly of elements of the base- and precious-metal suite and hydrothermal alteration suite in heavy-mineral-concentrate samples.

d) Weak geochemical anomaly of ore-related elements and only traces of silver in vein sample.

a) Silicified shear zones in contact-metamorphic rocks.

b) Chip samples of silicified rock had significant gold, minor silver, and moderate amounts of base metals.

a) Irregular silicified zones of granitic aplite host rock associated with the granite of Devils Gate-Mack Canyon in $10,000-\mathrm{ft}^{2}$ area.

b) Weak geochemical anomaly of elements of the base- and precious-metal suite in heavymineral-concentrate samples. c) No significant metal values in vein sample.

Molybdenum

The mineral resource potential for a disseminatedmolybdenum system associated with the Tertiary rhyolitic volcanic rocks is moderate. Host rocks, alteration, and geochemical and geophysical characteristics are favorable for this type of deposit; however, the mineralization event could have either concentrated or dispersed molybdenum.

The mineral resource potential for molybdenum in granite is low because altered and mineralized areas are small and only weakly favorable, the upper parts of granitic bodies where molybdenum may have been more likely to occur have been lost by erosion, and geophysical characteristics are not favorable.

The following tabulation lists areas with a molybdenum resource potential, evaluation of the areas as to potential, and a summary of data supporting the assignment of potential.

Area Resource

(fig. 3 potential

Ml Moderate

\section{Assessment criteria}

a) Intrusive and extrusive rhyolite
Area

(fig. 3)

esource

M

Low to moderate

M3

Low host rock of Sweetwater volcanic center.

b) Intensely altered epithermal silver veins and host rocks possibly indicating an underlying porphry system.

c) Strong geochemical anomaly of elements in stream-sediment samples and molybdenumtungsten, base- and preciousmetal, and hydrothermal alteration suites in concentrate samples.

d) Small gravity and aeromagnetic lows associated with intensely altered Tertiary and older rocks.

e) Altered and (or) mineralized rock samples contain background or trace to moderate molybdenum abundances.

f) Extensive prospecting by

M6 Low

\section{Assessment criteria}

numerous mining companies. a) Rhyolite host rock of Sweetwater volcanic center

b) Epithermal gold veins intensely altered host rocks.

c) Weak geochemical anomaly of elements of the molybdenumtungsten and hydrothermal alteration suites in heavymineral-concentrate samples. d) Small gravity and aeromagnetic lows.

a) Rhyolite host rock of the Sweetwater volcanic center. b) Epithermal gold and silver veins intensely argillized and silicified host rock.

c)Moderate to strong geochemical anomaly of elements in streamsediment samples, base- and precious-metal and hydrothermal alteration suites in heavymineral-concentrate samples.

d) Altered and (or) mineralized rock samples contain trace to moderate molybdenum abundances

a) Medium- to coarse-grained granite of East Fork host rock.

b) Sericite alteration and molybdenum mineralization restricted to area of $5,000 \mathrm{ft}^{2}$.

c) Strong geochemical anomaly of elements of the molybdenumtungsten and hydrothermal alteration suites in heavymineral-concentrate samples.

d) Altered and (or) mineralized rock samples contain low to moderate molybdenum and low tin abundances.

a) Fine-grained granitic intrusive phase of East Fork pluton host rock.

b) Leached, sericitized, and silicified host-rock envelope.

c) Quartz-molybdenite veinlets in altered rock.

d) Weak geochemical anomaly of elements of the molybdenumtungsten and hydrothermal alteration suites in heavymineral-concentrate samples.

e) Altered and (or) mineralized rock samples contain moderate molybdenum abundances.

a) The granites of East Fork and Green Creek host rock.

b) Sericitized and pyritized hostrock envelope with more intense alteration and silicification near veinlets.

c) Quartz-molybdenite veinlets exposed in two open cuts less than $100 \mathrm{ft}$ long.

d) Weak geochemical anomaly of elements of the molybdenumtungsten and base- and preciousmetal suites in heavy-mineralconcentrate samples. 


\section{Area Resource}

(fig. 3) potential

M7

Low
Assessment criteria

e) Altered and (or) mineralized rock samples contain low to high molybdenum abundances. f) Green Creek prospect has yielded small amounts of molybdenum from quartzmolybdenite veinlets.

a) Granite of East Fork host rock. b) Quartz-molybdenite veinlets in zone less than $100 \mathrm{ft}$ across. c) Weak geochemical anomaly of elements of the molybdenumtungsten suite in heavy-mineralconcentrate samples.

d) Altered and (or) mineralized rock samples contain moderate molybdenum abundances.

Iron and copper

The mineral resource potential for iron and copper contact-metasomatic deposits is low generally because favorable carbonate lenses are small in the metasedimentary host rocks and geophysical characteristics are not suggestive of large, dense, or highly magnetic bodies. The only exception is the iron deposit in Sweetwater Canyon which has a moderate potential because of its larger size and high iron content.

The following tabulation lists those areas with an iron and copper resource potential, evaluation of the areas as to potential, and a summary of data supporting the assignment of potential.

Area

Resource

IC3 (fig. 3)

potential

IC1

Low

IC2

Moderate

Low

Assessment criteria

a) Carbonate lenses in metasedimentary host rock.

b) The granite of Desert Creek exposed nearby to north.

c) Magnetite and traces of copper silicates or carbonates exposed in prospect pits.

d) Select samples average 24.2 percent iron.

e) Magnetic and gravity highs associated with eastern outcrops of metamorphic rocks.

a) Carbonate lenses in metasedimentary host rock.

b) Diorite and granite of the East Fork pluton in nearby exposures.

c) Magnetite-bearing lens approximately 6 by $1,000 \mathrm{ft}$.

d) Estimated occurrence of $1,000,000$ tons of ore with 52 percent iron in upper Sweetwater Canyon.

e) Magnetic low indicates a reversely polarized metamorphic rock body.

a) Host rock of carbonate lenses in metasedimentary rocks.

b) The granites of Devils GateMack Canyon and East Fork exposed nearby.

\section{Tungsten}

The resource potential for tungsten is low in spite of exposed and inferred favorable host rocks because geochemical anomalies for the molybdenum-tungsten suite of

elements are weak and rock samples contain background or very low tungsten abundances.

The following tabulation lists those areas with a tungsten resource potential, evaluation of the areas as to potential, and a summary of data supporting the assignment of potential.

Area Resource

(fig. 3) potential

w1 Low

W2

Low

W3

Low because of generally unfavorable host-rock type, weak controlling structure, and absence of extensive alteration. The following tabulation evaluates the one area as to uranium resource potential and lists a summary of data supporting the assignment of potential.

Area Resource

(fig. 3) potential

U1 Low The mineral resource potential for manganese is low because of unfavorable host-rock and mineral-deposit characteristics. The following tabulation lists those areas with manganese potential, evaluation of the areas as to potential, and a summary of data supporting the assignment of potential. 
Area

Resource potential

MN1 Low

MN2

Low

MN3

Low

\section{Assessment criteria}

a) Manganese oxide-bearing quartz vein, 8 in. wide by $5 \mathrm{ft}$ long.

a) Manganese-bearing area 150 $200 \mathrm{ft}$ in diameter by $15-20 \mathrm{ft}$ thick in weakly altered rhyolite; possible hot-spring origin.

b) Rock samples contain moderate to high manganese abundances.

a) 1- to 3-in. wide stringers and 1$\mathrm{ft}$-wide by 20 -ft-long breccia zone in rhyolite.

b) Botryoidal psilomelane and manganite(?).

c) High manganese abundance in breccia zone.

Silica

The mineral resource potential for silica is low because the pegmatitic quartz bodies are of relatively small size and are not in a geologically favorable environment. The following tabulation evaluates the one area as to silica resource potential and lists a summary of data supporting the assignment of potential.

\section{Area}

(fig. 3)

\section{Resource}

potential

S1 Low

\section{Assessment criteria}

a) Located in mafic complex of Swauger Creek near contact with the granite of Devils Gate-Mack Canyon.

b) Two vertical 300-ft-diameter quartz pegmatite bodies with feldspar shell; no indication of large controlling structure or presence of other nearby bodies.

Geothermal energy

The resource potential for geothermal energy is low in the vicinity of Fales Hot Springs based primarily on the relatively old age of the potential igneous heat source and unfavorable reservoir characteristics. The following tabulation evaluates the one area as to geothermal energy resource potential and lists a summary of data supporting the assignment of potential.

\begin{tabular}{ll} 
Area & Resource \\
(fig. 3) & potential \\
\hline
\end{tabular}

\section{Assessment criteria}

Gl Low

a) Hot springs located on ring fracture of Little Walker volcanic center; most favorable volcanic reservoir rock located south of study area.

b) Current activity may be related to opening of fractures along old ring-fracture system as youngest volcanic activity associated with volcanic center is late Miocene. c) Reservojr volume estimated to be $0.8 \mathrm{mi}^{3}$ with temperature of $241^{\circ} \mathrm{F}$ (Muffler, 1979).

\section{REFERENCES CTTED}

Bradley, W. W., 1927, Silver, in California mineral production for 1926: California Division of Mines and Mining Bulletin 100, p. 59-61.

Brem, G. F., 1977, Petrogenesis of late Tertiary potassic voleanic rocks in the central Sierra Nevada and western Great Basin: Riverside, Calif., University of California, Ph. D. thesis, 361 p.

-1982, Sweetwater rhyolite center, Sweetwater Mountains. Mono County, California and Lyon County, Nevada abs : Geological Society of America Abstracts with Programs, v. 14, no. 4, p. 152.

1983, Geologic map of the Sweetwater Roadless Area, Mono County, California, and Lyon and Douglas Counties, Nevada: U.S. Geological Survey Miscellaneous Field Studies Map MF-1535-B, scale 1:62,500.

Chaffee, M. A, 1983, SCORESUM-A technique for displaying and evaluating multielement geochemical information, with examples of its use in regional mineral assessment programs: Journal of Geochemical Exploration, v.19, no. 1-3.

Dickinson, W. R. 1976, Sedimentary basins developed during evolution of Mesozoic-Cenozoic arc-trench system in western North America: Canadian Journal of Earth Science, v. 13, p. 1268-1287.

1979, Cenozoic plate tectonic setting of the Cordilleran region in the United States, in Armentrout, J. M., Cole, M. R., and Terbest, H., Jr., eds: Cenozoic paleogeography of the western United States, Pacific Section Society of Economic Paleontologists and Mineralogists, Symposium 3, p. 1-13.

Dickinson and Snyder, W. S., 1979, Geometry of subducted slabs related to the San Andreas Transform: Journa of Geology, v. 87, p. 609-627.

Eakle, A. A., and McLaughlin, R. P., 1917, Patterson district, in Mono County: California State Mining Bureau Report XV of the State Mineralogist, v. 15, p. 160-167.

Halsey, J. G., 1953, Geology of parts of the Bridgeport, California, and Wellington, Nevada quandrangles: Berkeley, Calif., University of California, $\mathrm{Ph}$. $\mathrm{D}$. thesis, $497 \mathrm{p}$.

Hanks, H. G., 1884, Mono County: California State Mining Bureau Fourth Annual Report of the State Mineralogist, v. 4, p. 363-364.

Hunter, R. D., 1976, Volcanic stratigraphy and structural control of mineralization in the northeastern portion of the Patterson mining district, Mono County, California: Riverside, Calif., University of California, M.A. thesis, 135 p.

Lambeth, R. H., Cambell, H. W., Scott, D. F., and Spear, J. M., 1983, Mineral investigation of the Sweetwater RARE II Area (No. 4-657), Mono County, California, and Douglas and Lyon Counties, Nevada: U.S. Bureau of Mines Open File Report MLA-69-83.

Muffler, L. J. P., 1979, Assessment of geothermal resources of the United States - 1978: U.S. Geological Survey Circular 790, $163 \mathrm{p}$.

Plouff, Donald, 1982a, Gravity observations in the Walker Lake $1^{6} \times 2^{\circ}$ quadrangle, California-Nevada: U.S. Geological Survey Open-File Report 82-405, 105 p.

$1982 \mathrm{~b}$, Map showing gravity and magnetic surveys of the Hoover Wilderness and adjacent study area, Mono and Tuolumne Counties, California: U.S. Geological Survey Miscellaneous Field Studies Map MF-1101-C, scale $1: 62,500,2$ sheets.

Schweickert, R. A., 1972, Shallow level intrusions in the eastern Sierra Nevada, California: Stanford, Calif., Stanford University, Ph. D. thesis, 85 p.

1976, Shallow level plutonic complexes in the eastern Sierra Nevada, California and their tectonic implications: Geological Society of America Special Paper $176,58 \mathrm{p}$.

Sutley, S. J., Chaffee, M. A., Brem, G. F., Fey, D. L, and Hill, R. H., 1983, Chemical analyses and statistical summaries for samples of rock, minus-60-mesh $(0.25$ $\mathrm{mm}$ ) stream sediment, and nonmagnetic heavy-mineral concentrate, Sweetwater Roadless Area, Mono County, California, and Lyon and Douglas Counties, Nevada: U.S. Geological Survey Open-File Report 83-647, 44 p. 1 plate.

Symons, H. H., 1928, Silver, in California mineral production for 1927: California Division of Mines and Mining Bulletin 101, D. 58-60.

1929, Silver, in California mineral production for 1928: 
California Division of Mines and Mining Bulletin 102, p. $60-62$.

1935, Silver, in California mineral production and directory of mineral producers for 1934: California Division of Mines and Mining Bulletin 111, p. 59-61.

1936, Silver, in California mineral production and directory of mineral producers for 1935: California Division of Mines and Mining Bulletin 112, p. 48-49.

1937, Silver, in Californis mineral production and directory of mineral producers for 1936: California Division of Mines and Mining Bulletin 114, p. 46-48.

1938, Silver, in California mineral production and directory of mineral producers for 1937: California Division of Mines and Mining Bulletin 116, p. 46-47.

1939, Silver, in California mineral production and directory of mineral producers for 1938: California Division of Mines and Mining Bulletin 117, p. 49-52.
Tucker, W. B., 1927, Lead, silver, and zine, in Mono County: California Division of Mines and Mining Report XXII of the State Mineralogist, v. 23, p. 374-406.

U.S. Geological Survey, 1979, Aeromagnetic map of the Hoover-Walker Lake area, California: U.S. Geological Survey Open-File Report 79-1194, scale 1:250,000.

U.S. Geological Survey, 1982, Aeromagnetic map of the Sweetwater area, California and Nevada: U.S. Geological Survey Open-File Report 82-66, scale $1: 62,500$.

VanTrump, George, Jr., and Miesch, A. T., 1977, The U.S. Geological Survey RASS-STATPAC system for management and statistical reduction of geochemical data: Computers and Geosciences, v. 3, p. 475-488.

Whiting, E. M., 1888, Patterson mining district, in Mono County: California State Mining Bureau Eighth Annual Report of the State Mineralogist, v. 8, p. 357-363. 


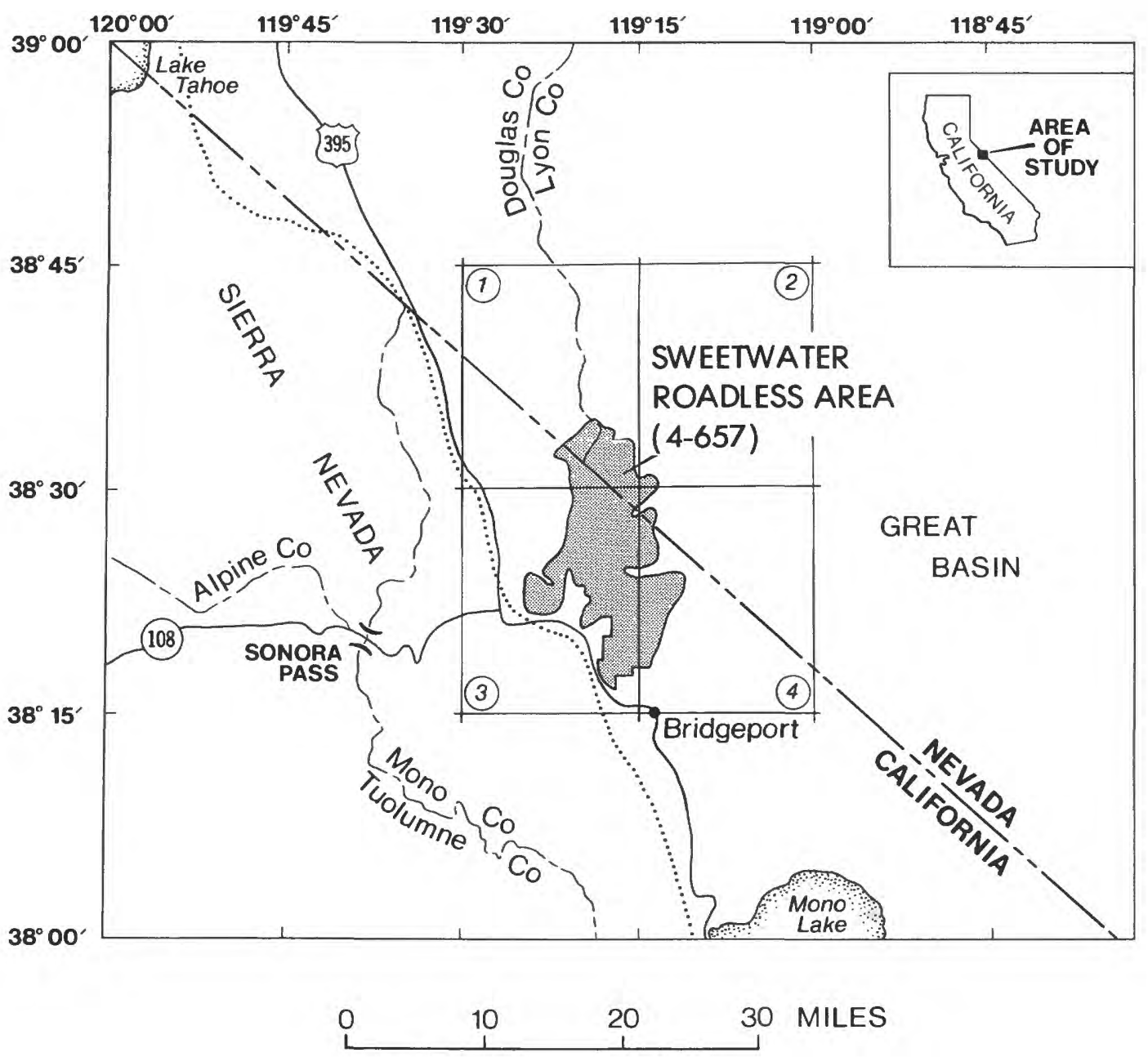

Figure 1.-Location of Sweetwater Roadless Area, Calif. and Nev. Numbers indicate 15minute quadrangles; 1, Desert Creek Peak, 2, Pine Grove Hills, 3, Fales Hot Springs, 4, Bridgeport. Dotted line represents approximate boundary between Sierra Nevada and Basin and Range provinces. 


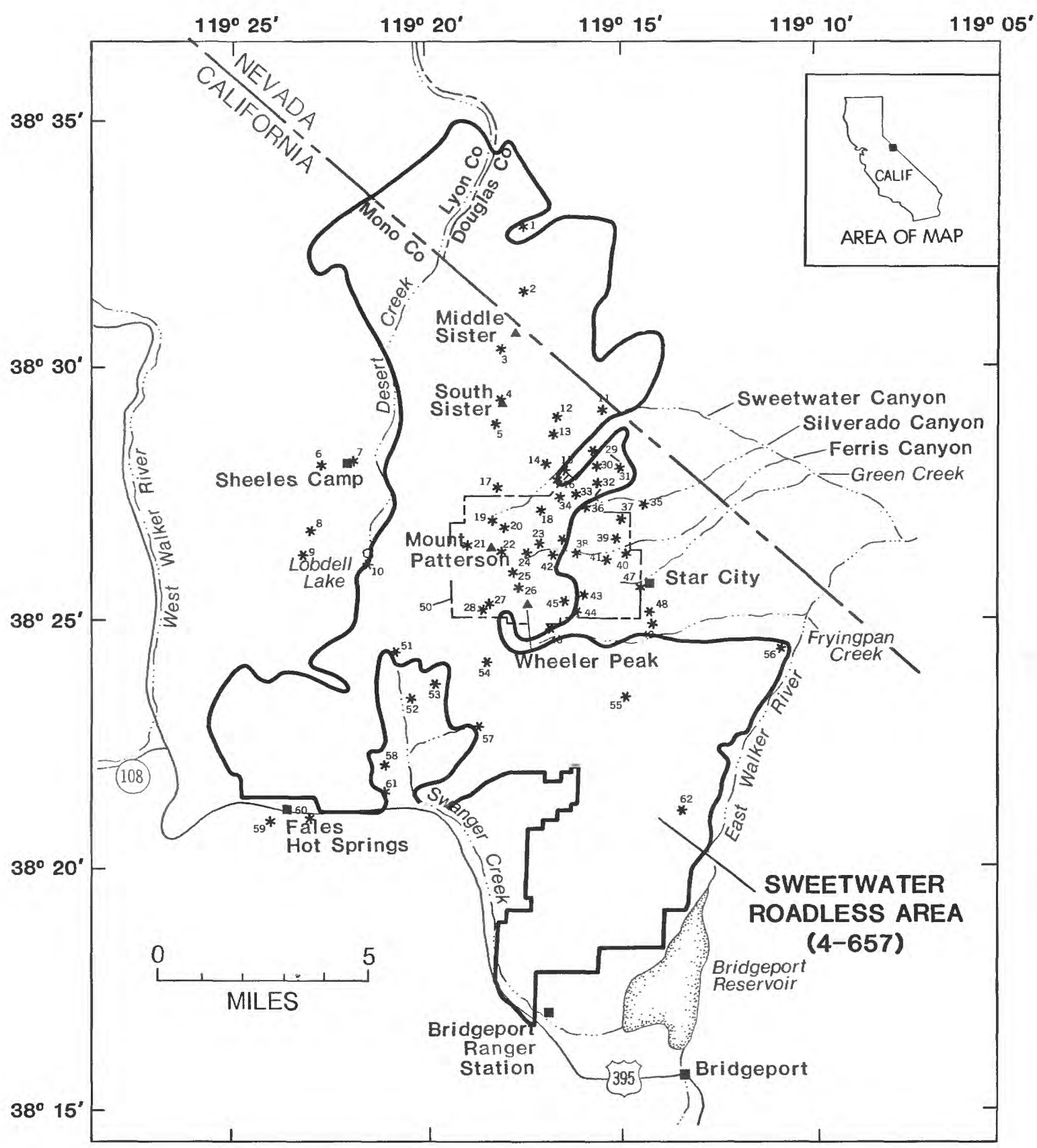

Figure 2.-Locations of mines and prospects in the Sweetwater Roadless Area. Numbers refer to list of mines and prospects and table 1 . 


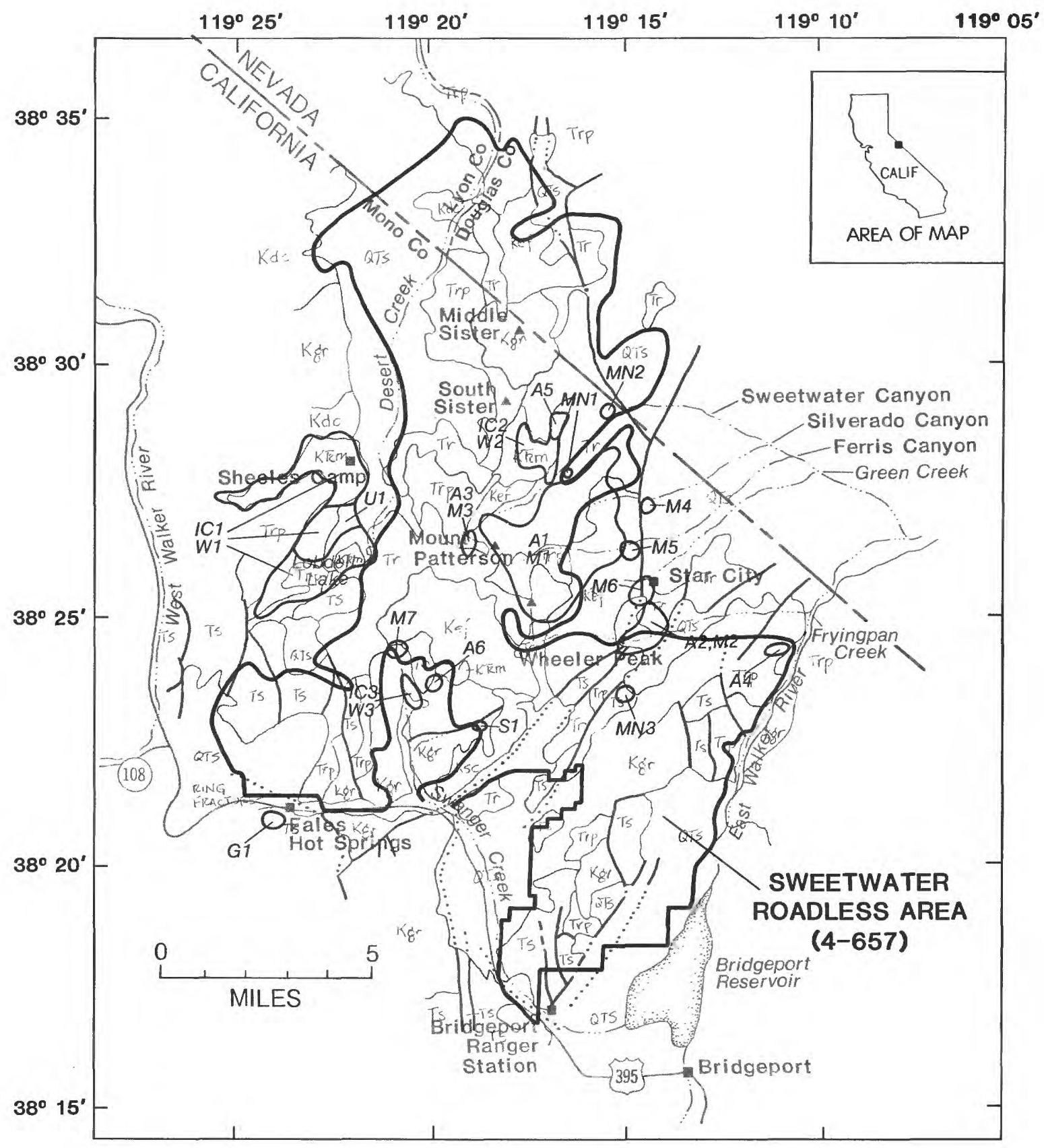

Figure 3.- Sweetwater Roadless Area, showing areas of mineral resource potential. Complete muneral resource assessment is tabulated in text. 
DESCRIPTION OF MAP UNITS

SEDIMENTARY DEPOSITS

SURFICIAL DEPOSITS (QUATERNARY AND TERTIARY?)-Alluvium and landslide deposits

\section{VOLCANIC ROCKS}

Tr

Trp

$\mathrm{Kgr}$

Kef

Kde

Ksc

KR $\mathbf{m}$
STANISLAUS GROUP (MIOCENE)-Latite from the Little Walker volcanic center

RHYOLITE OF SWEETWATER MOUNTAINS (MIOCENE)-Rhyolite pyroclastic, lava flow, and intrusive rocks

RELIEF PEAK AND VALLEY SPRINGS FORMATIONS, UNDIVIDED (MIOCENE AND OLIGOCENE)-Andesite effusive rocks with very minor silicic welded tuff

PLUTONIC ROCKS

GRANITE OF DEVILS GATE-MACK CANYON, ROCK CREEK, TAYLOR VALLEY, MIDDLE SISTER, AND BELFORT, UNDIVIDED (CRETACEOUS)-Granite and granitic aplite

GRANITE OF EAST FORK AND GREEN CREEK, UNDIVIDED (CRETACEOUS)-Porphyritic granite, locally metamorphosed or altered

GRANITE OF DESERT CREEK (CRETACEOUS)-Granular to porphyritic granite; metamorphosed

MAFIC COMPLEX OF SWAUGER CREEK (CRETACEOUS)-Layered gabbroic complex; metamorphosed

METAMORPHIC ROCKS

METAMORPHIC ROCKS (CRETACEOUS, JURASSIC, AND (OR) TRIASSIC)-Thermally metamorphosed sedimentary and voleanic rocks

CONTACT

FAULT-Dotted where inferred

APPROXIMATE BOUNDARY OF SWEETWATER ROADLESS AREA

\section{EXPLANATION}

AREA OF MINERAL RESOURCE POTENTIAL-Letters refer to metals, nonmetals, or metallic suites; numbers designate unique areas discussed in text. Line patterns are combined when more than one mineral occurs within a given area. Complete mineral resource assessment is tabulated in text

PRECIOUS METALS (GOLD AND SILVER)

High

High

Moderat

Low

Low

MOLYBDENUM

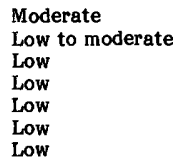

IRON AND COPPER

TUNGSTEN

\section{MNl}

MN2

MN3

Sl

Gl
MANGANESE

Low

Low

SILICA

Low

GEOTHERMAL ENERGY

$$
\text { Low }
$$

MINE OR PROSPECT-Numbers refer to list of mines and prospects and table 1 of accompanying pamphlet.

MINES AND PROSPECTS

1. Rickey mine

2. Golden Rule prospect

3. Unnamed prospect

4. Unnamed pospect

5. Unnamed prospect

6. Iron King prospect

7. Unnamed prospect

8. C and B prospect

9. Unnamed prospect

10. Lobdell Lake prospect

11. Unnamed prospect

12. Apollo prospect

13. E. G. No. 1 prospect

14. Iron Cap prospect

15. Penrose (Lucky Joe) prospect

16. Unnamed prospect

17. Unnamed prospect

18. Unnamed prospect

19. Star and Great Western prospect

20. Angelo Mission mine

21. Montague mine

22. California Comstock prospect

23. Unnamed prospect

25. Sweetwater Rose prospect

26. Unnamed prospect

27. Unnamed prospect

28. Unnamed prospect

29. Unnamed prospect

30. Silverado Extension No. 3 prospect

31. Unnamed prospect

32. Cottonwood Canyon prospect

33. Unnamed prospect

34. Red Dog prospect

35. Unnamed próspect

36. Silverado mine

37. Unnamed prospect

38. Kentuck mine

39. Tiger I mine

40. Tiger II mine

41. Unnamed prospect

42. Unnamed prospect

43. Frederick mine

44. Brederick mine

45. Boulder Flat prospect

46. $M$ and $T$ prospect

46. M and T prospect
47. Green Creek prospect

47. Green Creek prospect

49. Monte Cristo min

50. AMAX prospect

51. Pits prospect

52. Unnamed prospect

53. Longstreet mine

54. Unnamed prospect

55. Black Horse prospect

56. Sims prospect

57. Unnemed prospect

58. Quartz Hill No. 6 prospect

59. Fales Hot Springs

60. Red Gold prospect

61. Unnamed prospect 


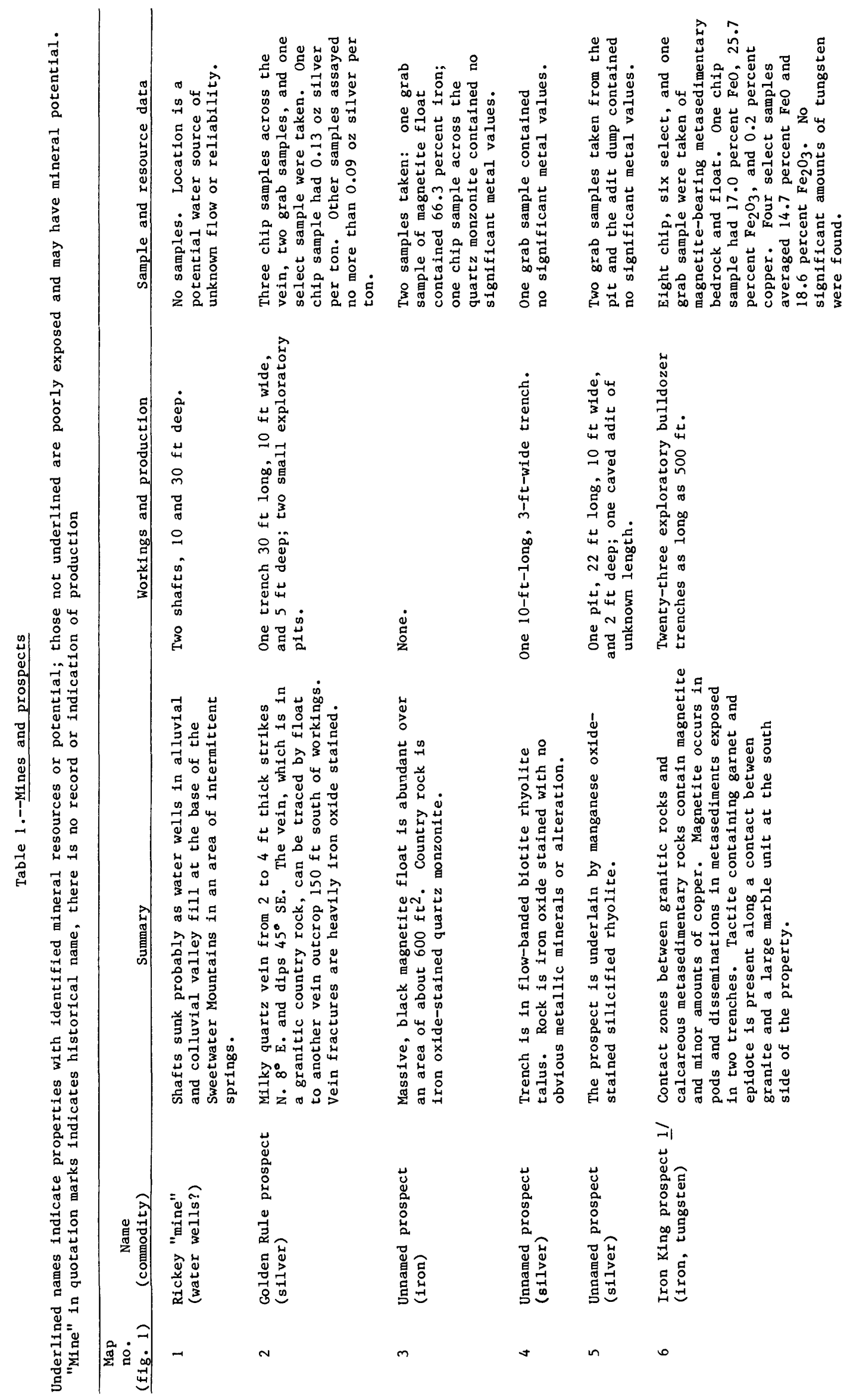



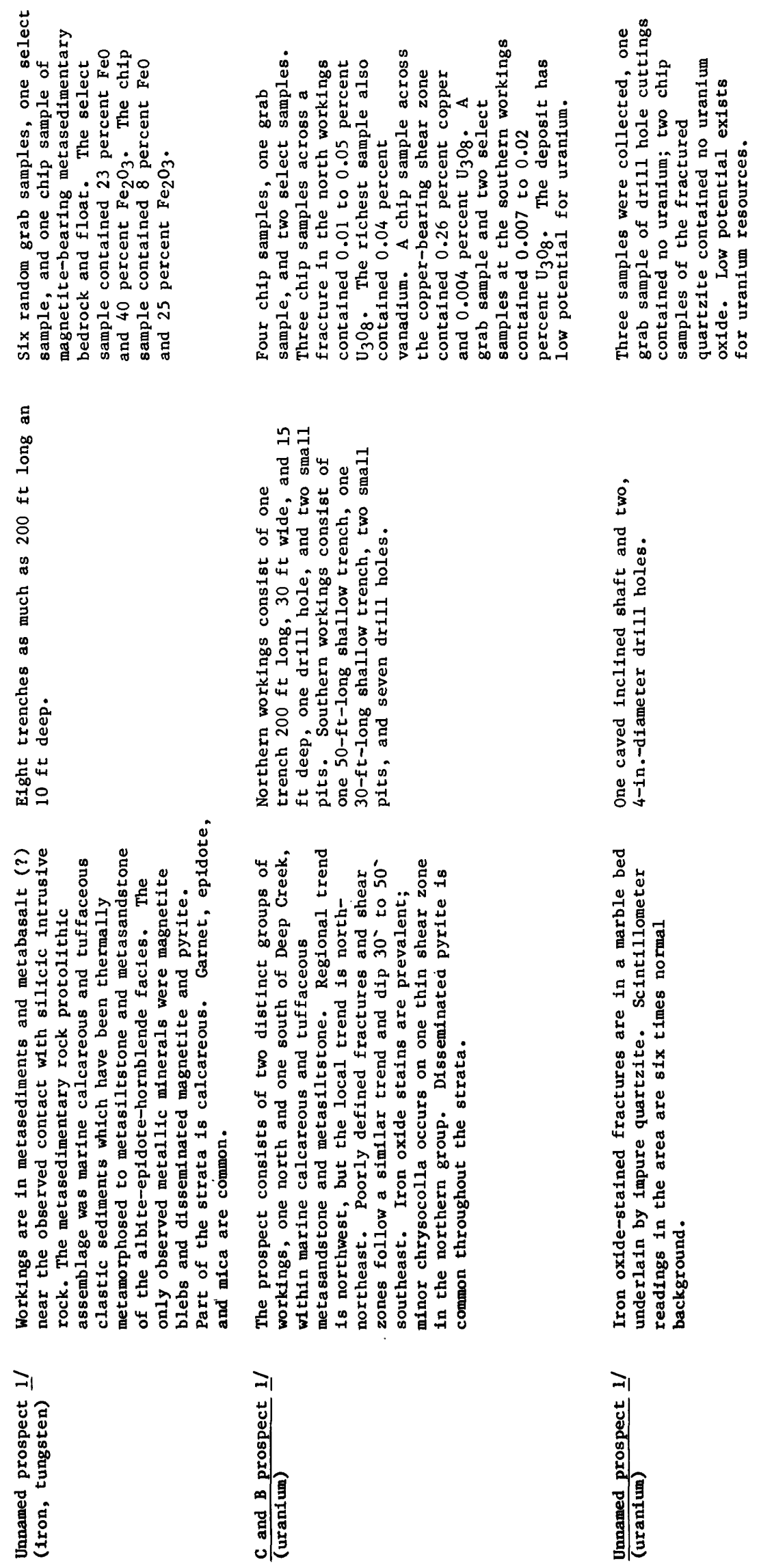


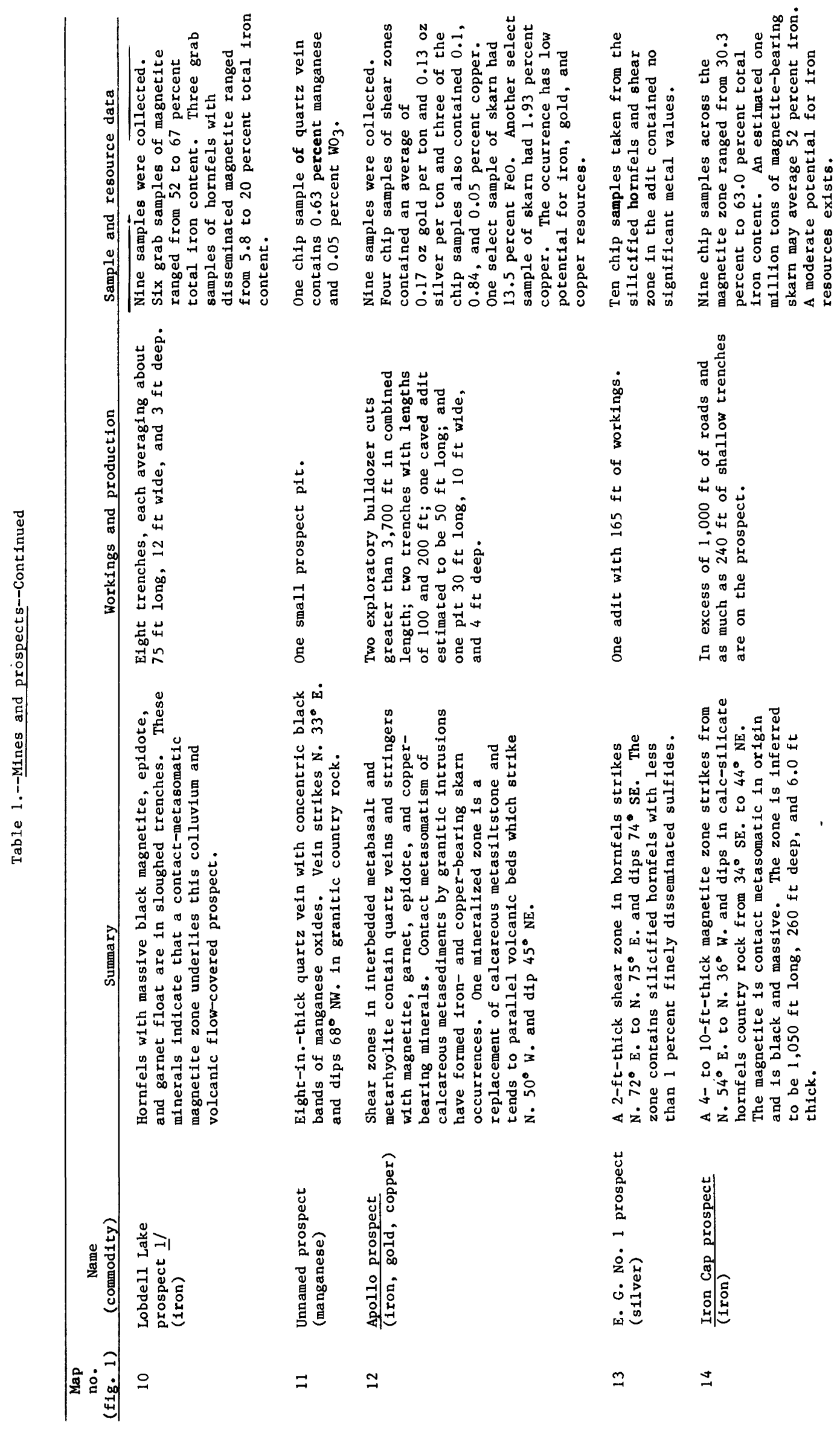



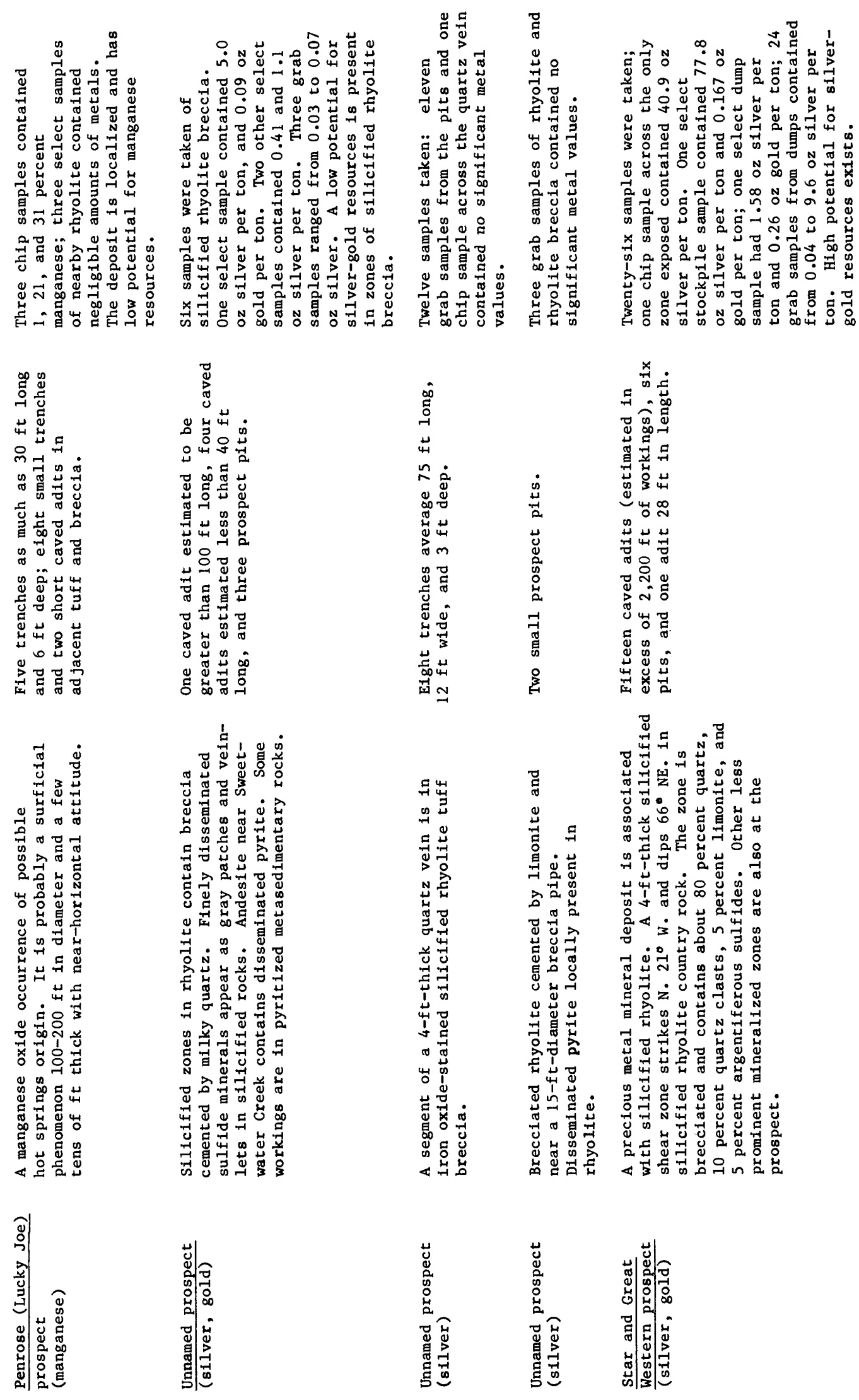

n

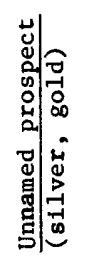

$=\stackrel{\infty}{\rightarrow}$ 


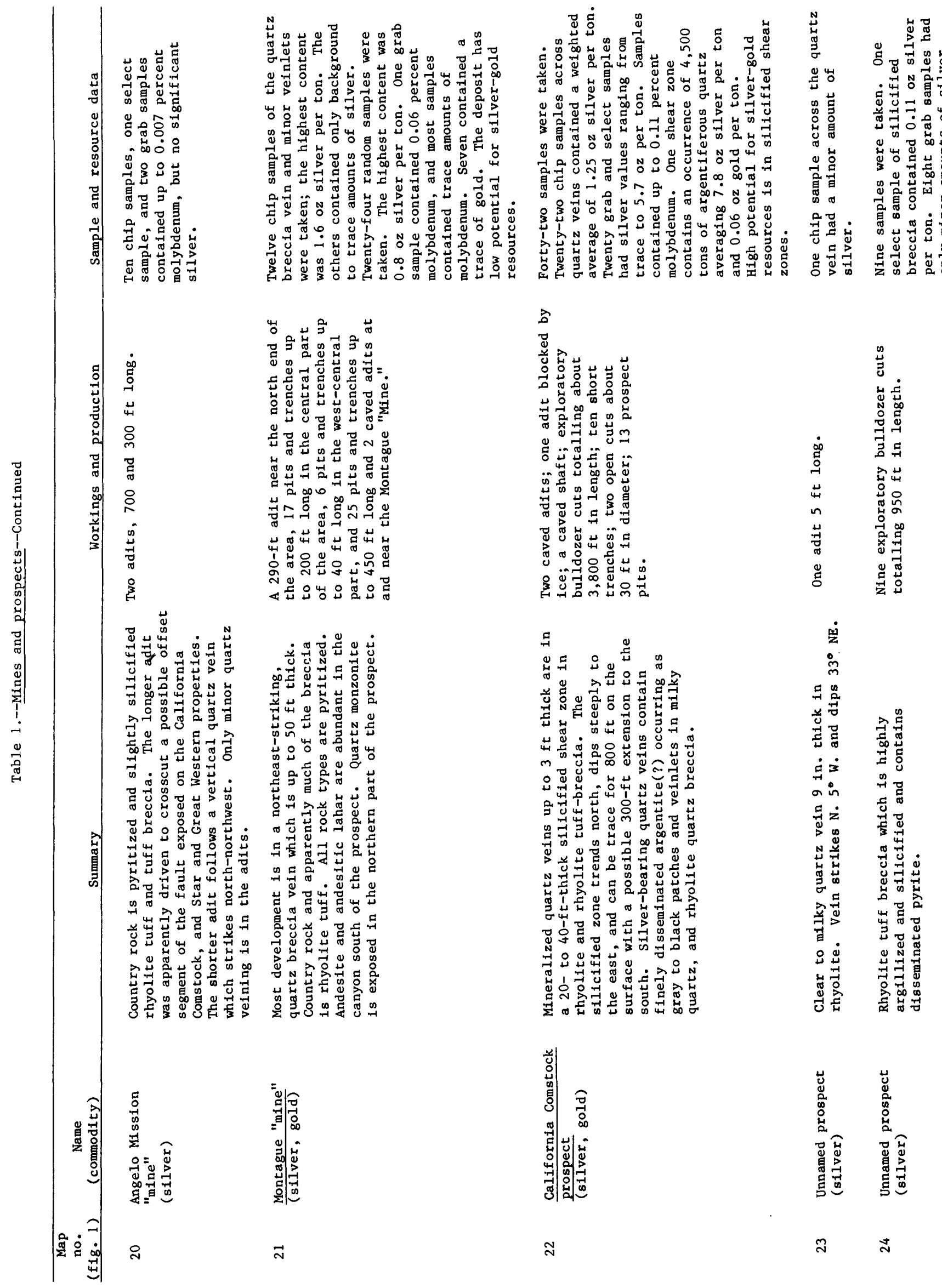




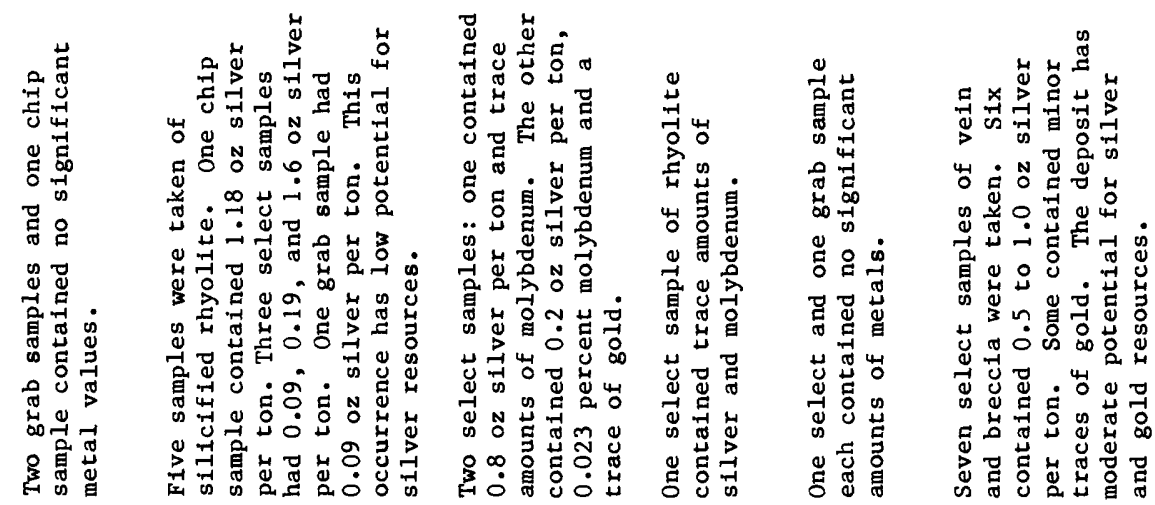
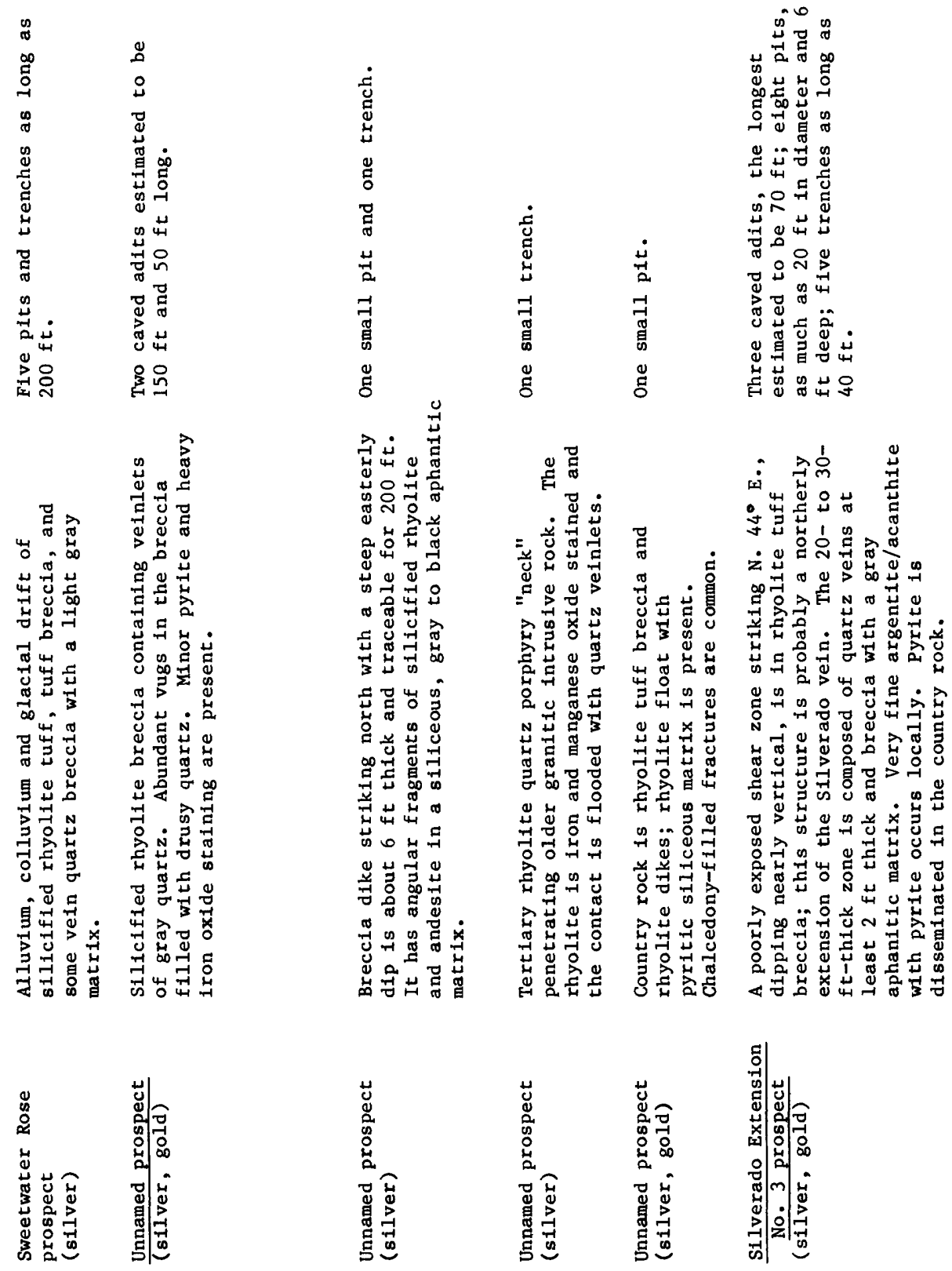

N

$\stackrel{\circ}{2}$

$\hat{n}$

$\stackrel{\infty}{N}$

ลิ

요 


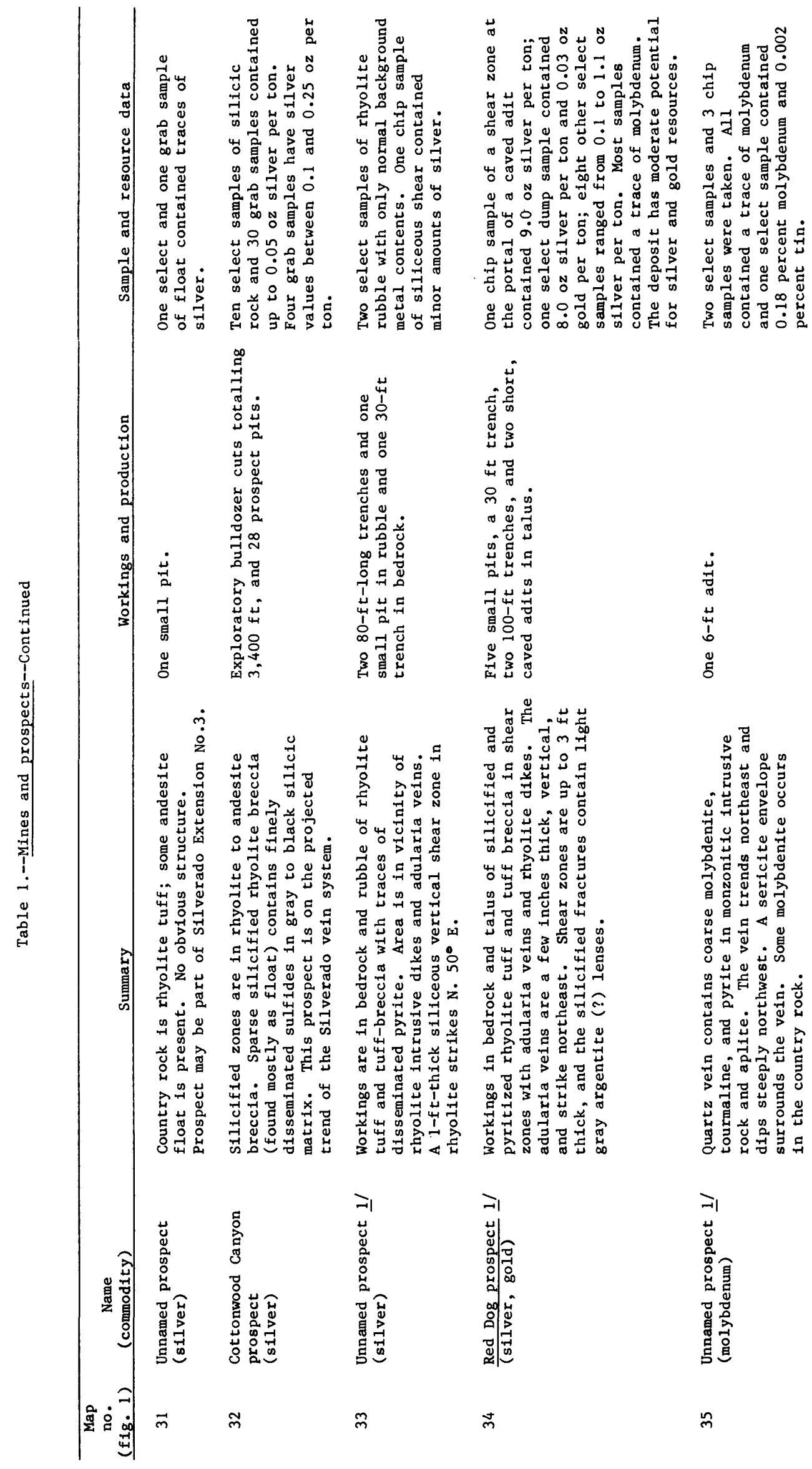



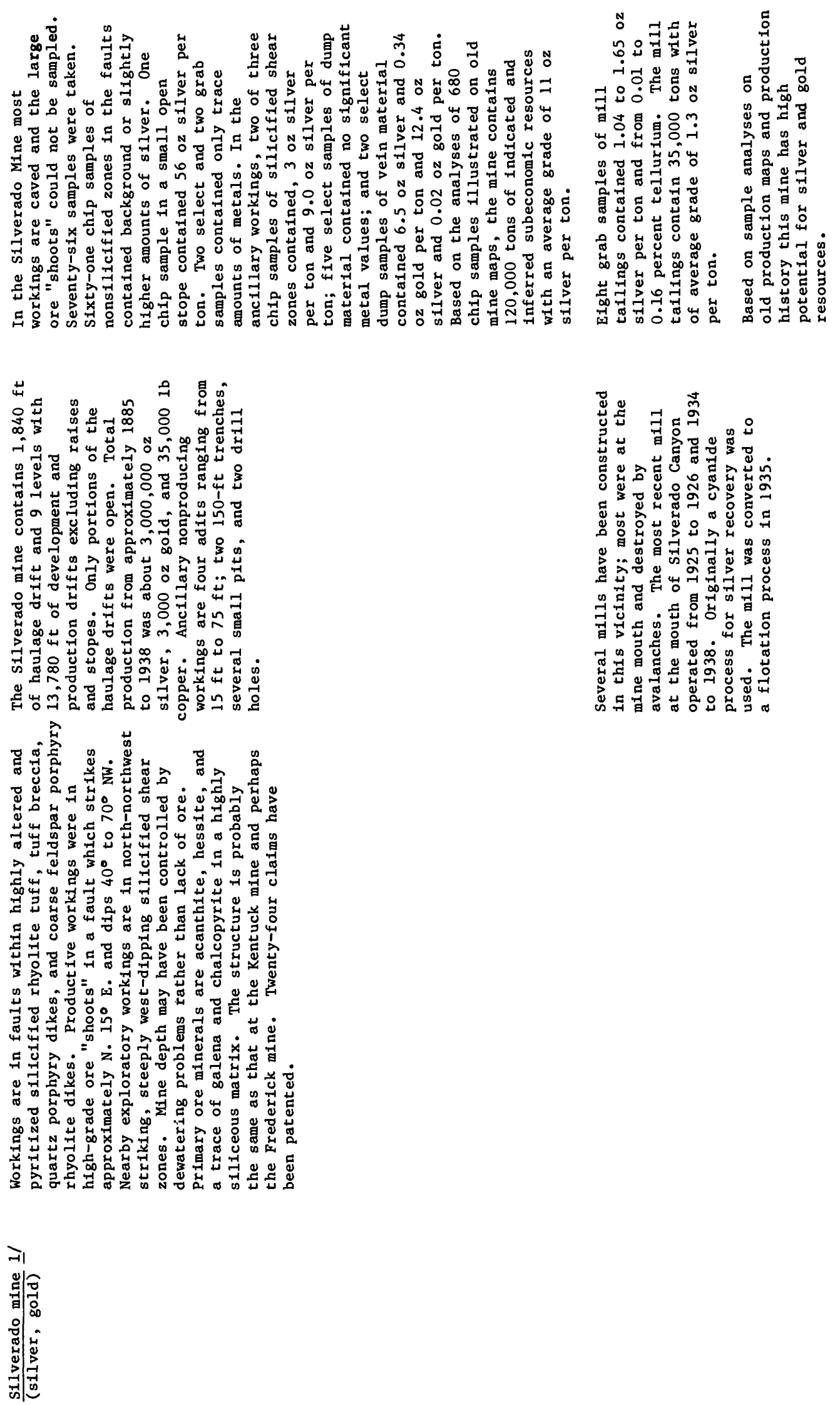


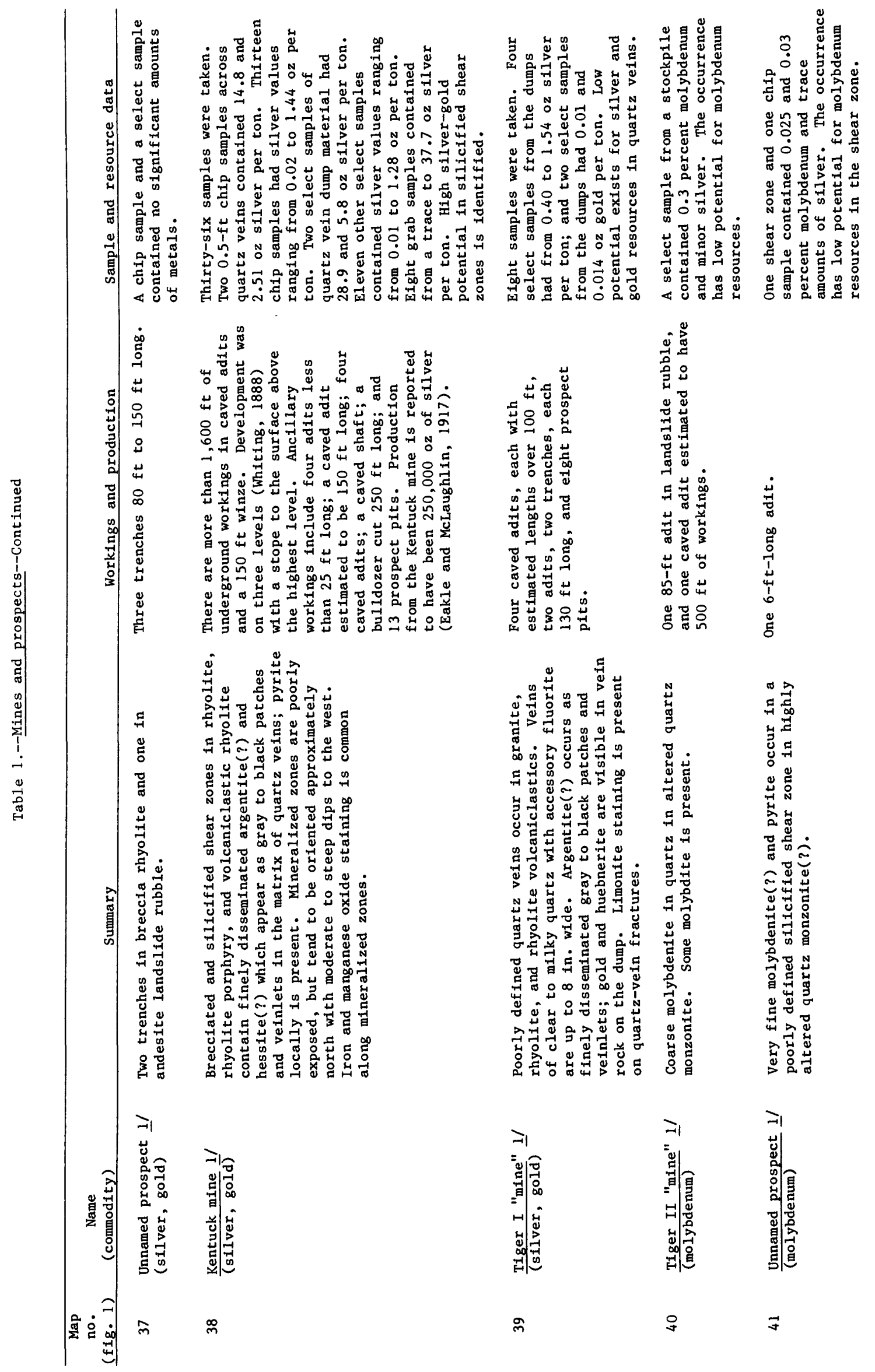




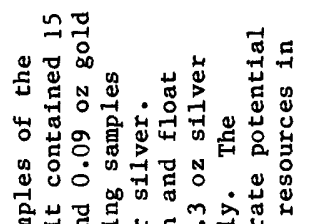

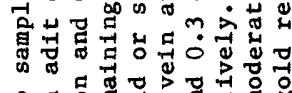

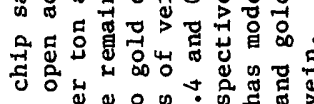

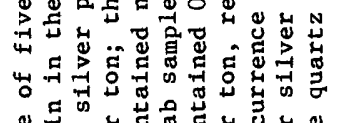

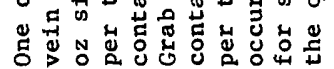

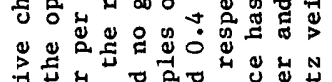

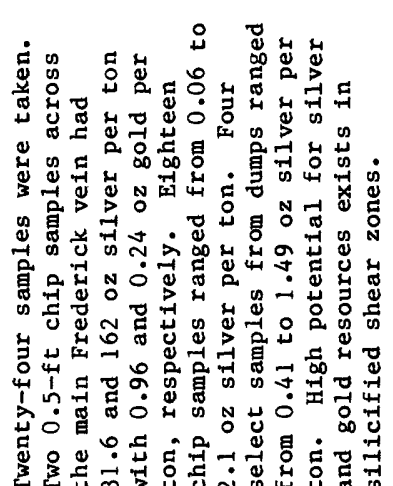

䑻出

궁ํำ

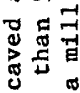

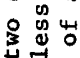

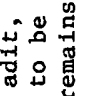

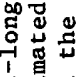

战葛

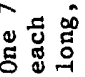
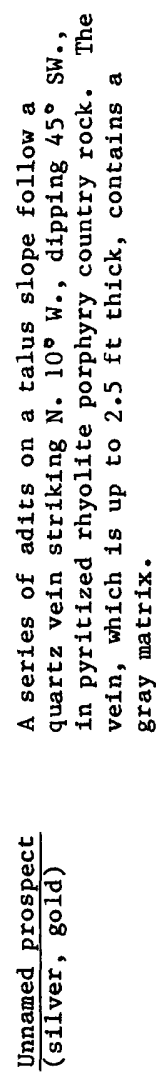

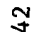

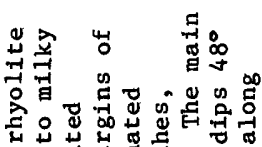

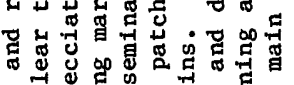

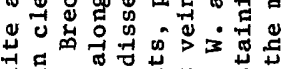

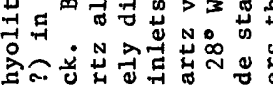

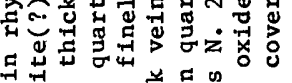

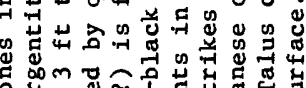

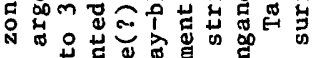

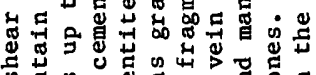

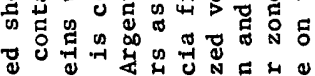

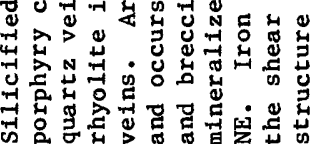

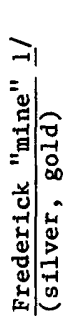

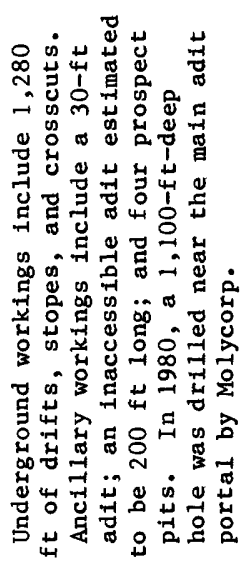

$\stackrel{m}{9}$

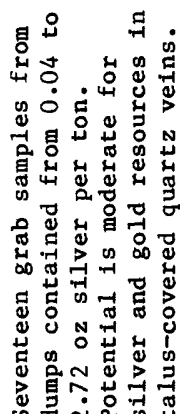

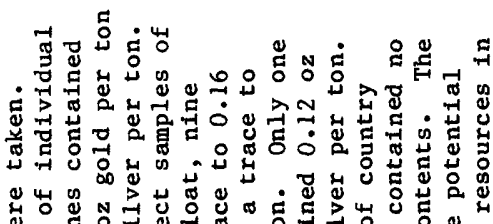

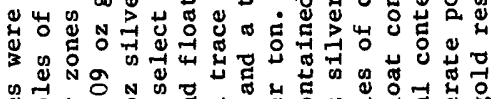

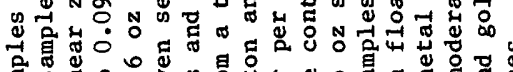

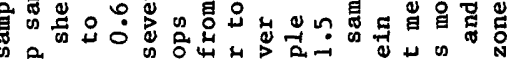
क :

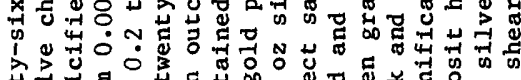

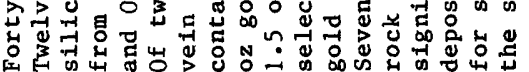

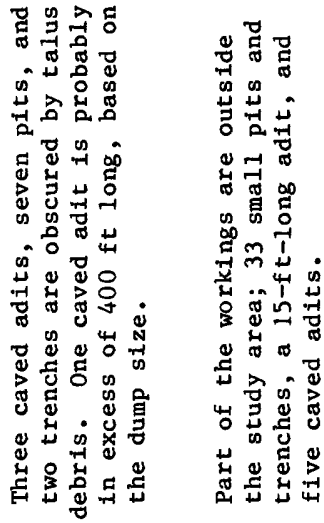
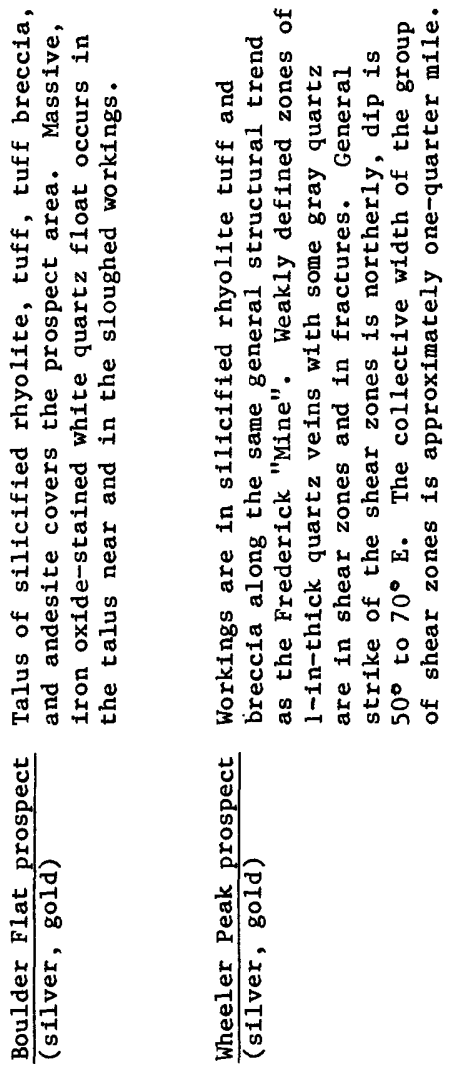

\&

q 


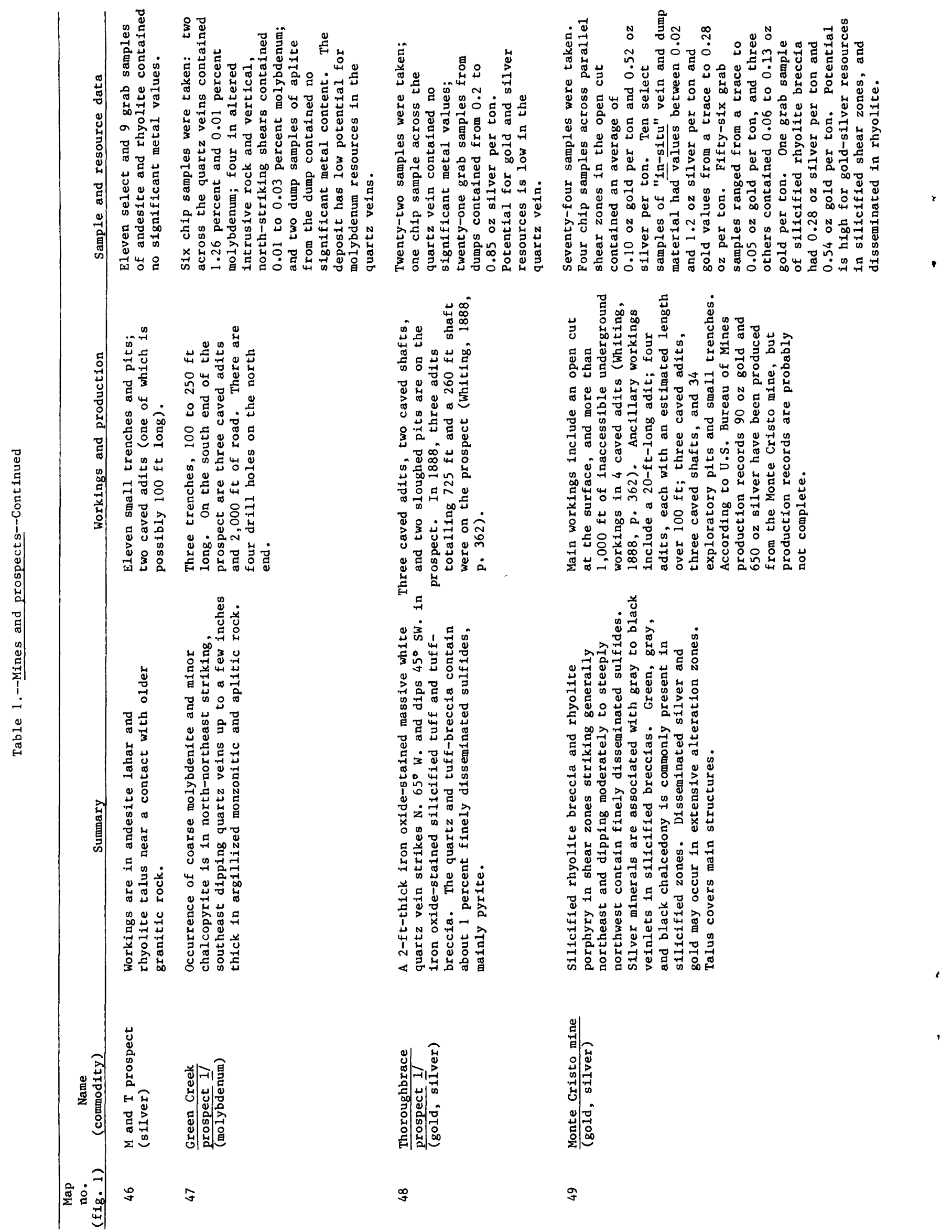




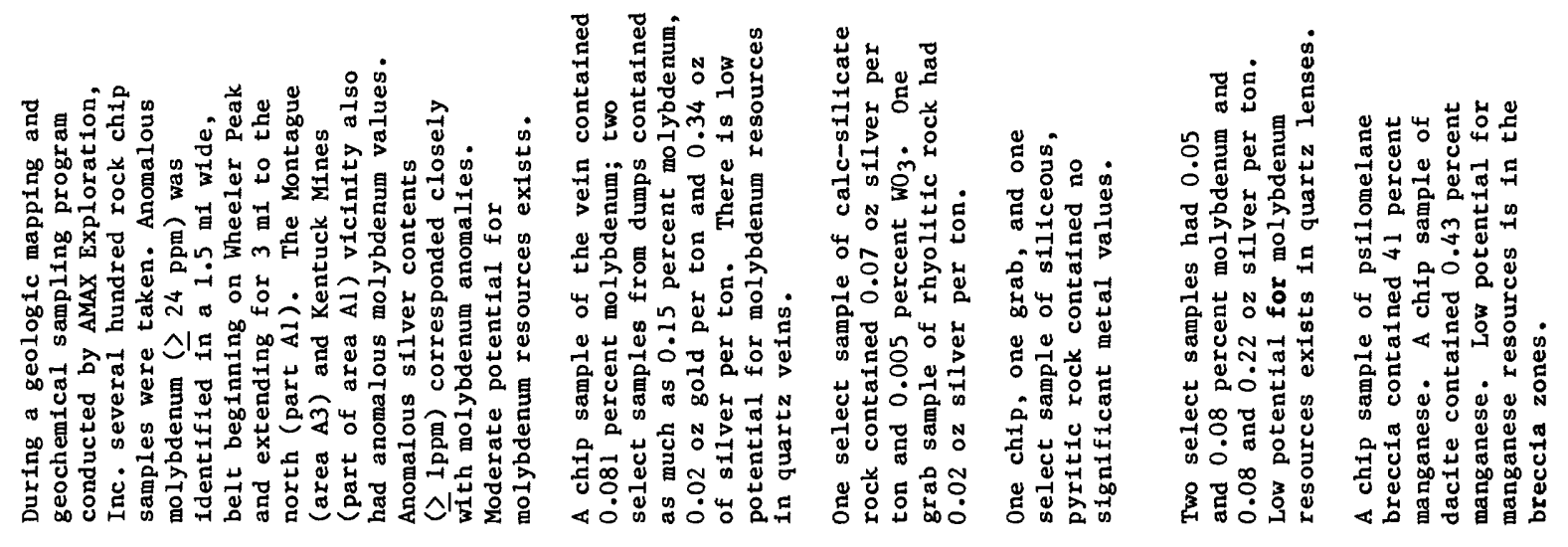

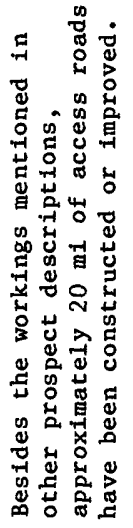

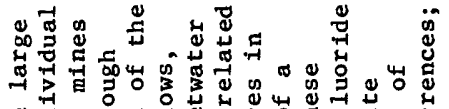

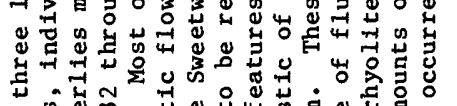

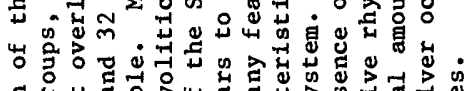

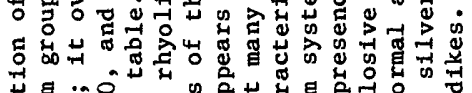

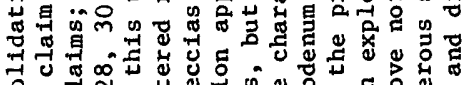

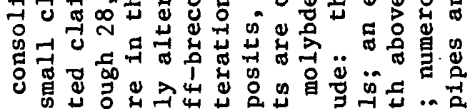

का

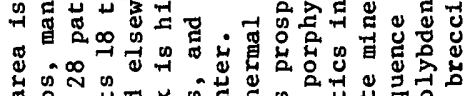

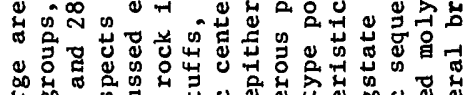

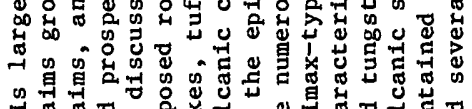

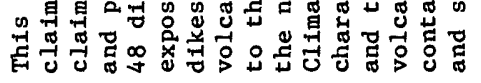

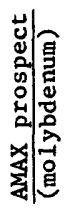

in

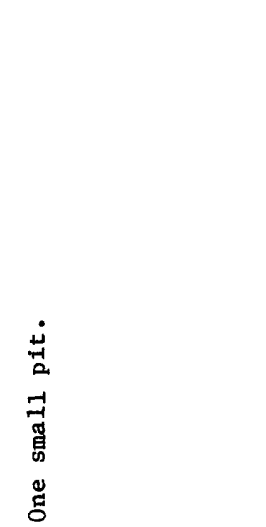

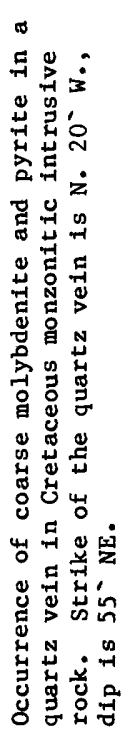

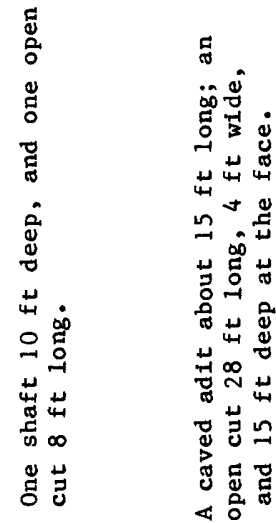

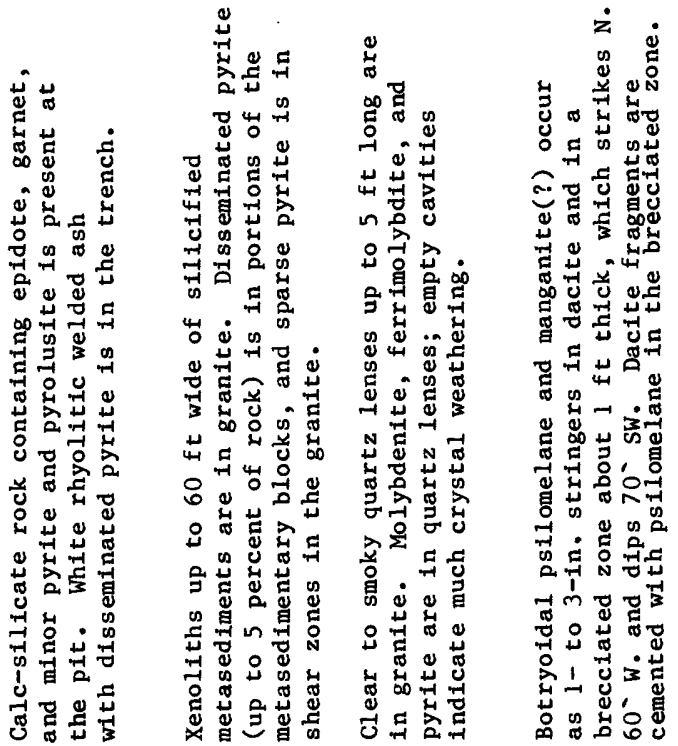

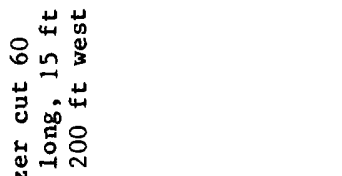

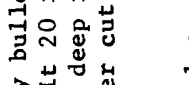

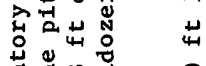

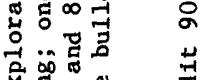

ช.

茛出霡岁

\&
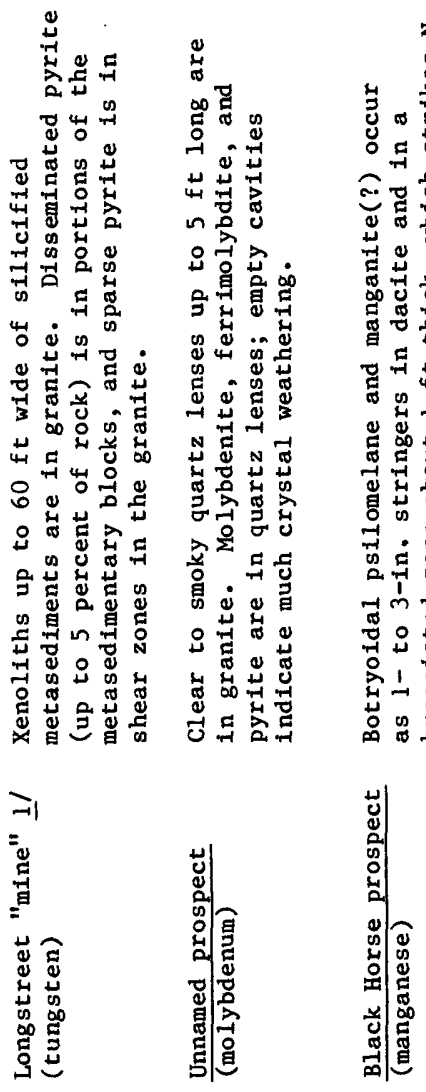

$\vec{n}$

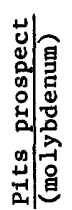

$\vec{n}$

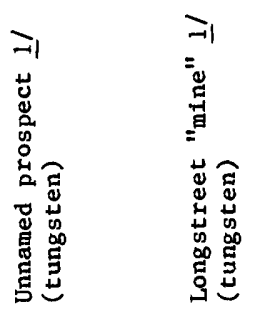

ก in

ถูก 


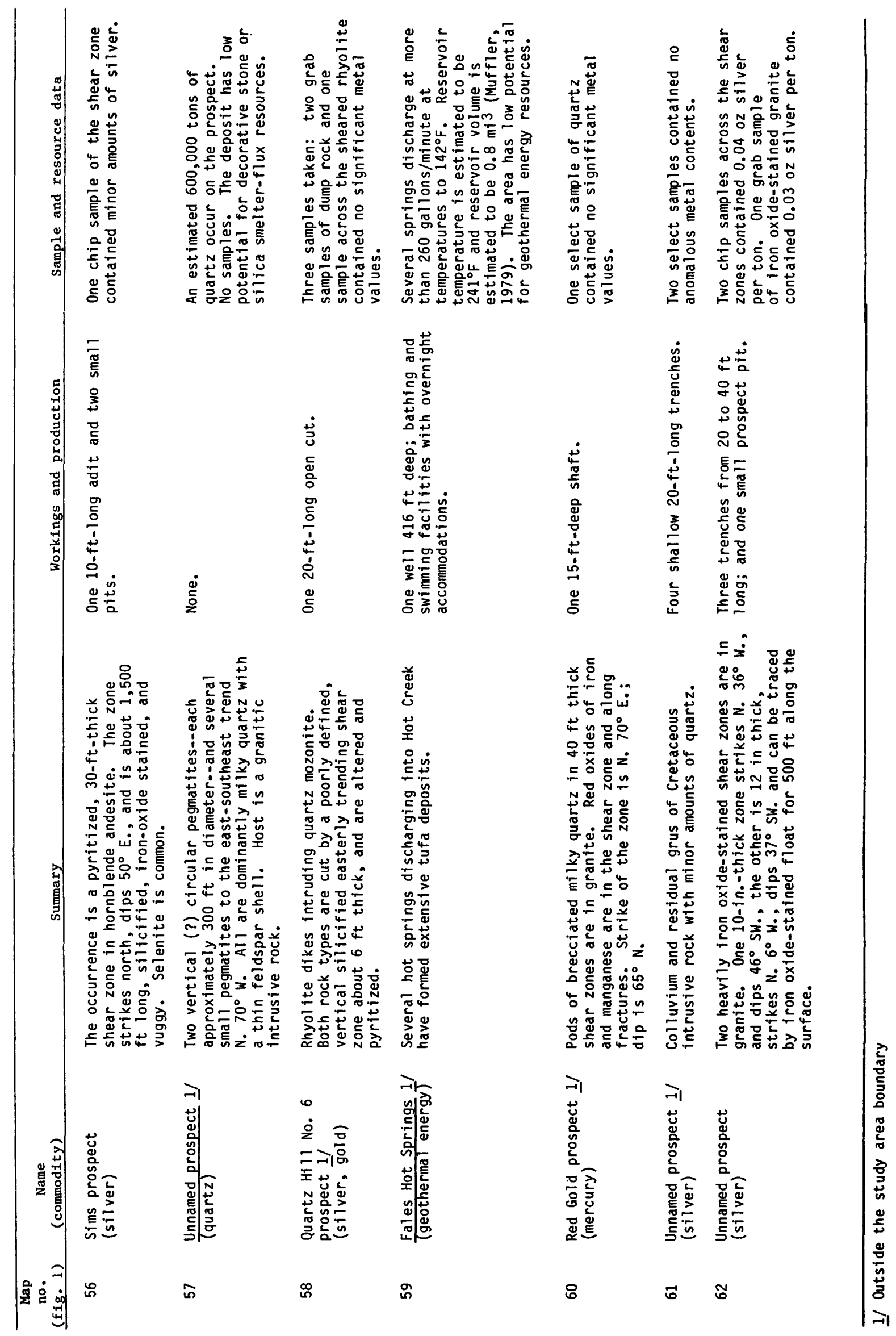

